Working Paper/Document de travail 2012-27

\title{
Systematic Risk, Debt Maturity and the Term Structure of Credit Spreads
}

by Hui Chen, Yu Xu and Jun Yang 
Bank of Canada Working Paper 2012-27

August 2012

\title{
Systematic Risk, Debt Maturity and the Term Structure of Credit Spreads
}

by

\author{
Hui Chen, ${ }^{1} \mathrm{Yu} \mathrm{Xu}{ }^{2}$ and Jun Yang ${ }^{3}$ \\ ${ }^{1}$ MIT Sloan and NBER \\ huichen@mit.edu \\ ${ }^{2}$ MIT Sloan \\ yu_xu@mit.edu \\ ${ }^{3}$ Financial Markets Department \\ Bank of Canada \\ Ottawa, Ontario, Canada K1A 0G9 \\ junyang@bankofcanada.ca
}




\section{Acknowledgements}

We thank Jennifer Carpenter, Chris Hennessy, Burton Hollifield, Nengjiu Ju, Thorsten Koeppl, Jun Pan, Monika Piazzesi, Ilya Strebulaev, Wei Xiong and seminar participants at the Texas Finance Festival, the Bank of Canada Fellowship Workshop, the China International Conference in Finance, the Summer Institute of Finance at Qingdao, the NBER's Summer Institute Asset Pricing Workshop, London School of Economics, and London Business School for comments. 


\begin{abstract}
We build a dynamic capital structure model to study the link between systematic risk exposure and debt maturity, as well as their joint impact on the term structure of credit spreads. Our model allows for time variation and lumpiness in the maturity structure. Relative to short-term debt, long-term debt is less prone to rollover risks, but its illiquidity raises the costs of financing. The risk premium embedded in the bankruptcy costs causes firms with high systematic risk to favour longer debt maturity, as well as a more stable maturity structure over the business cycle. Pro-cyclical debt maturity amplifies the impact of aggregate shocks on the term structure of credit spreads, especially for firms with high leverage or high beta, and for firms with a large amount of long-term debt maturing when the aggregate shock arrives. However, endogenous maturity choice can also reduce and even reverse the effect of rollover risk on credit spreads. We provide empirical evidence for the model predictions on both debt maturity and credit spreads.
\end{abstract}

JEL classification: G32, G33

Bank classification: Asset pricing; Debt management

\title{
Résumé
}

À l'aide d'un modèle dynamique de la structure de capital, les auteurs étudient le lien entre l'exposition des entreprises au risque systématique et l'échéance de leur dette, ainsi que les incidences conjointes de ces deux facteurs sur la structure par terme des écarts de crédit. Dans leur modèle, la structure des échéances peut varier dans le temps et être irrégulière. Les obligations à long terme sont moins sensibles au risque de refinancement que les titres à court terme, mais leur illiquidité a pour effet d'alourdir les coûts d'emprunt. La prime de risque intégrée aux coûts de faillite amène les firmes très exposées au risque systématique à préférer une dette à plus long terme et une structure des échéances plus stable sur le cycle économique. La procyclicité des échéances amplifie les répercussions des chocs globaux sur la structure par terme des écarts de crédit, surtout dans le cas des entreprises fortement endettées ou dont les titres affichent un bêta élevé et de celles qui ont un volume considérable d'obligations à long terme échéant au moment du choc global. Cependant, le choix endogène de l'échéance peut également atténuer, voire inverser, les effets du risque de refinancement sur les écarts de crédit. Les auteurs testent empiriquement la validité des prévisions de leur modèle concernant l’échéance de la dette et les écarts de crédit.

Classification JEL : G32, G33

Classification de la Banque : Évaluation des actifs; Gestion de la dette 


\section{Introduction}

The aggregate corporate debt maturity has a clear cyclical pattern: the average debt maturity is longer in economic expansions than in recessions. Using data from the Flow of Funds, Figure 1 shows the trend and cyclical components of the share of long-term debt for nonfinancial firms from 1952 to 2010. The average drop in the cyclical component of the long-term debt share from peak to trough is $4 \% .^{1}$ These facts raise important questions both for corporate debt maturity management and for corporate bond pricing. First, do firms with different exposures to aggregate risks behave differently in their debt maturity choices? Second, given that a shorter debt maturity tends to raise rollover risk, how much does the cyclical variation in debt maturity amplify the fluctuations in credit risk over the business cycle?

Our paper addresses these two questions using a dynamic capital structure model with maturity choice. A firm faces business cycle fluctuations in growth, economic uncertainty, and risk premia. It chooses how much debt to issue based on the trade-off between the tax benefits of debt and the costs of financial distress. Default occurs due to equity holders' inability to commit to servicing its debt, especially when debt needs to be rolled over at high yields. A longer debt maturity helps reduce this rollover risk. At the same time, long-term bonds are more costly to issue than short-term bonds due to illiquidity, which we model in reduced form. The debt maturity choice balances these tradeoffs.

In the model, systematic risk affects maturity choice through two channels. For firms with high systematic risk, liquidation is more likely to occur in aggregate bad times. Thus, the risk premium associated with the deadweight losses of default will raise the expected bankruptcy costs for these firms, causing them to choose longer debt maturity during normal times. Next, in recessions, the costs of issuing long-term debt relative to short-term debt become higher because of the larger liquidity discount for long-term bonds. On the one hand, firms with low systematic risk exposure respond by replacing the bonds that is maturing in recessions with short-term bonds, which lowers their average debt maturity. On the other

\footnotetext{
${ }^{1}$ The sample mean of long-term debt share is $62 \%$. We do not study the long-term trend in debt maturity in this paper. Greenwood, Hanson, and Stein (2010) argue that this trend is consistent with firms acting as macro liquidity providers.
} 

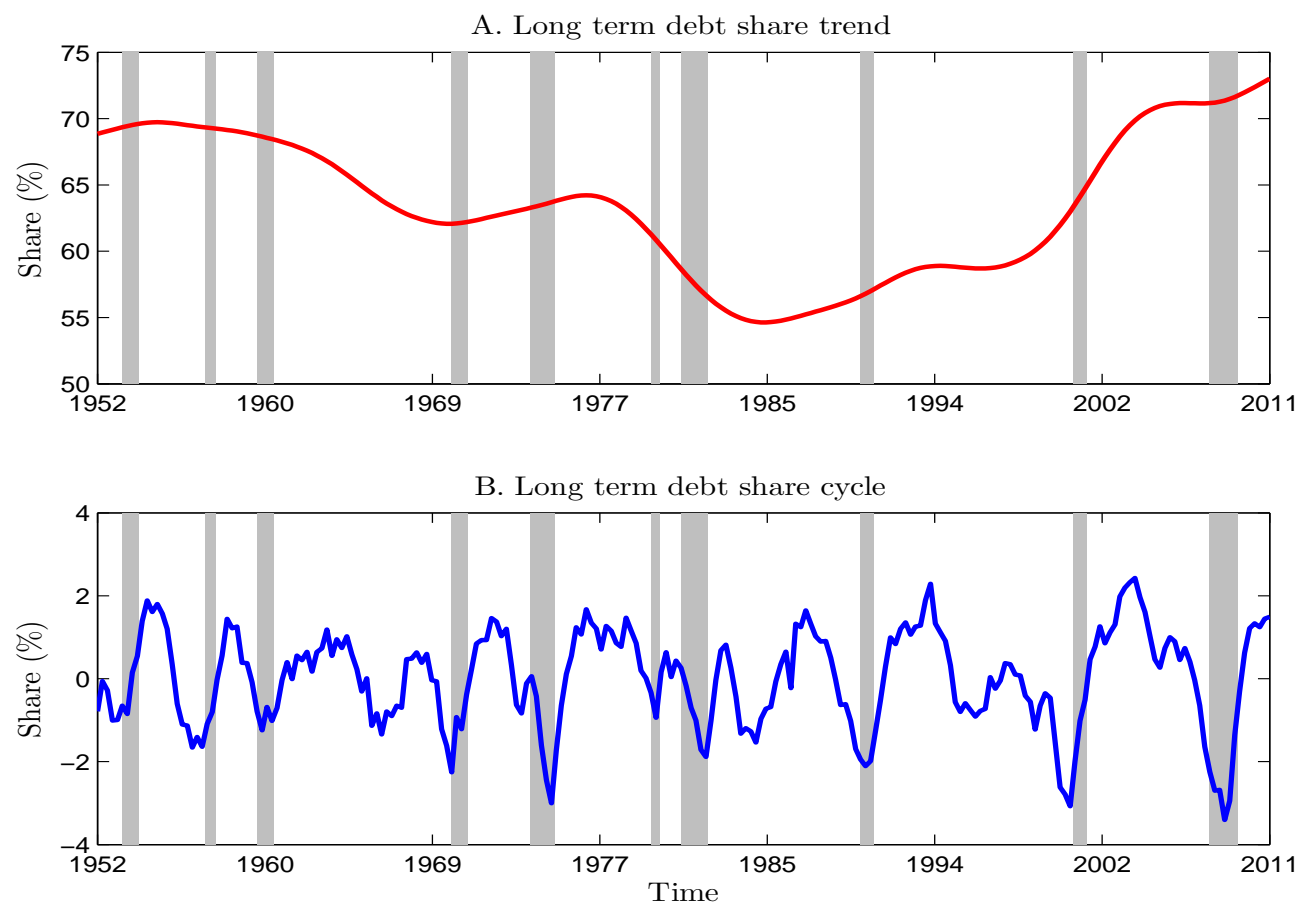

Figure 1: Long-term debt share for nonfinancial corporate business. The top panel plots the trend component (via the Hodrick-Prescott filter) of aggregate long-term debt share. The bottom panel plots the cyclical component. The shaded areas denote NBER-dated recessions. Source: Flow of Funds (Table L.102).

hand, firms with high systematic risk become even more concerned about the rollover risk associated with short maturity, which offsets the higher liquidity costs of long-term bonds. These firms will continue to roll over the matured bonds into new long-term bonds. As a result, their debt maturity will be relatively stable over the business cycle.

Our calibrated model generates reasonable predictions for leverage, default probabilities, credit spreads, and equity Sharpe ratios. Through the model, we also analyze the impact of debt maturity structure on the term structure of credit spreads.

First, compared to the case of a time-invariant maturity structure, procyclical maturity raises a firm's default risk and amplifies the fluctuations in its credit spreads over the business cycle. In our calibration, for a low-leverage firm, a moderate reduction in debt maturity from 5.5 years to 5 years in a recession has almost no effect on the credit spreads, whereas a reduction to 1 year can cause the credit spreads to rise by up to $90 \mathrm{bps}$. The amplification 
effect is stronger for firms with high beta or high leverage, and especially when a firm has a large amount of long-term debt retiring in bad times.

Second, the dynamics in the maturity structure affect different parts of the term structure of credit spreads differently. When a firm has moderate leverage, having a large amount of long-term debt expiring soon is not a concern in good times, because the firm expects to be able to roll over the debt into new long-term debt at low costs. Thus, its credit spreads will be almost the same as a firm that currently has long debt maturity. If a large amount of debt is coming due in a recession, the maturity effect on credit spreads gets stronger, but only shows up for medium-term credit spreads and has almost no impact on the short end of the credit curve. For a high-leverage firm, the effect of short maturity is not only much stronger, particularly in recessions, but is more concentrated at the short-end of the credit curve, which reflects the short-term nature of the rollover problem the firm faces.

Third, the endogenous link between systematic risk and debt maturity plays a key role in determining the effect of rollover risk on credit spreads. Choosing a longer maturity and a more stable maturity structure over the business cycle helps firms with high systematic risk reduce the fluctuations in their credit spreads. Still, the effect of high systematic risk tends to dominate that of debt maturity. As a result, when we sort firms in the cross section based on debt maturity, the credit spreads for firms with longer maturity can be not only higher on average, but also more sensitive to aggregate shocks.

We test the model implications on the link between systematic risk and debt maturity using firm-level data from 1974 to 2010. Consistent with the model, we find that firms with high systematic risk choose longer debt maturity and maintain a more stable maturity structure over the business cycle. After controlling for total asset volatility and leverage, a one-standard deviation increase in asset market beta raises firm's long-term debt share (the percentage of total debt that matures in more than 3 years) by $6.5 \%$. In addition, worsening macroeconomic conditions reduce firms' debt maturities, especially for firms less exposed to systematic risk. For a firm with its asset market beta at the 10th percentile, its long-term debt share is $3.7 \%$ lower in recessions than in expansions. For a firm with its asset market 
beta at the 90th percentile, its long-term debt share is almost unchanged from expansions to recessions. These findings are robust to different measures of systematic risk and different proxies for debt maturity. Finally, using data from the recent financial crisis, we also find evidence that the impact of rollover risk on credit spreads is significantly stronger for firms with high leverage or high beta, and it is stronger for shorter maturity.

An earlier empirical study by Barclay and Smith (1995) finds that firms with higher asset volatility choose shorter debt maturity. They do not separately examine the effects of systematic and idiosyncratic risks. Baker and Wurgler (2002) show that the fraction of long-term debt in net issuance predicts future excess bond returns negatively. They suggest that firms look at inflation, the real short-term rate, and the term spread to determine the maturity that minimizes the cost of capital. Two recent studies have documented that firms' debt maturity changes over the business cycle. Erel, Julio, Kim, and Weisbach (2011) show that new debt issuances shift towards shorter maturity and more security during times of poor macroeconomic conditions. Mian and Santos (2011) show that the effective maturity of syndicated loans is procyclical, especially for credit worthy firms. Our measure of systematic risk exposure is distinct from their measures of credit quality. They also argue that firms actively managed their loan maturity before the financial crisis through early refinancing of outstanding loans.

The main contribution of our paper is two-fold. First, it provides both a theory and empirical evidence for the link between systematic risk and firms' active maturity management in the cross section and over time. It adds to the growing body of research on how aggregate risk affects corporate financing decisions, which includes Almeida and Philippon (2007), Acharya, Almeida, and Campello (2010), Bhamra, Kuehn, and Strebulaev (2010b), Bhamra, Kuehn, and Strebulaev (2010a), Chen (2010), Chen and Manso (2010), and Gomes and Schmid (2010), among others.

Second, our paper contributes to the studies of the term structure of credit spreads. ${ }^{2}$

\footnotetext{
${ }^{2}$ Earlier contributions include structural models by Chen, Collin-Dufresne, and Goldstein (2009), CollinDufresne and Goldstein (2001), Duffie and Lando (2001), Leland (1994), Leland and Toft (1996), Zhou (2001), and reduced-form models by Duffie and Singleton (1999), Jarrow, Lando, and Turnbull (1997), Lando (1998), among others.
} 
Structural models can endogenously link default risk to firms' financing decisions, such as leverage and maturity structure. This is valuable for credit risk modeling, because while intuitive, it is far from obvious how the debt maturity structure actually affects credit risk at different horizons. For simplicity, most earlier models restrict the maturity structure to be time-invariant. We relax this restriction by allowing the maturity structure to be lumpy and to change over the business cycle. Thus, our model helps demonstrate how systematic risk affects the dynamics of debt maturity, which in turn affects the term structure of default risks. Moreover, lumpy maturity structure is prevalent in practice (see Choi, Hackbarth, and Zechner (2012)) and gives rise to the scenario of having a large amount of long-term debt retiring when the aggregate state of the economy changes, a feature exploited by Almeida, Campello, Laranjeira, and Weisbenner (2011) to identify the real effects of financial frictions.

Our model builds on the dynamic capital structure models with optimal choices for leverage, maturity, and default decisions. The disadvantage of short-term debt in these models is that debt rollover causes excessive liquidation. Possible costs for long-term debt include bond illiquidity (He and Milbradt (2012)), information asymmetry and adverse selection (Diamond (1991), Flannery (1986)), or agency problems (Leland and Toft (1996)). We focus on the cost of illiquidity because it can be directly calibrated to the data. Bao, Pan, and Wang (2011), Chen, Lesmond, and Wei (2007), Edwards, Harris, and Piwowar (2007), and Longstaff, Mithal, and Neis (2005) have all documented a significant positive relation between maturity and various measures of corporate bond illiquidity.

\section{Model}

In this section, we present a dynamic capital structure model that captures the link between debt maturity and systematic risk. A firm has exogenous cash flows that are exposed to the risks of the business cycle. It makes its capital structure decisions in an optimal trade-off framework. Besides the trade-off between the tax benefits and bankruptcy costs of debt, the firm is concerned with the rollover risk of short-term debt and the liquidity costs of long-term debt, which affects its choice of debt maturity. 


\subsection{The economy and the firm}

The state of the economy is described by a two-state, continuous-time Markov chain with the state denoted by $s_{t} \in\{G, B\}$, where $G$ represents an expansion state and $B$ a recession state. The physical transition intensities from state $G$ to $B$ and from $B$ to $G$ are $\pi_{G}^{\mathbb{P}}$ and $\pi_{B}^{\mathbb{P}}$, respectively, which means that between $t$ and $t+\Delta$, the economy will switch from state $G$ to $B(B$ to $G)$ with probability $\pi_{G}^{\mathbb{P}} \Delta\left(\pi_{B}^{\mathbb{P}} \Delta\right)$ approximately. In addition, it implies that the stationary probability of the expansion state is $\pi_{B}^{\mathbb{P}} /\left(\pi_{B}^{\mathbb{P}}+\pi_{G}^{\mathbb{P}}\right)$.

We assume an exogenous stochastic discount factor (SDF) $\Lambda_{t}:{ }^{3}$

$$
\frac{d \Lambda_{t}}{\Lambda_{t^{-}}}=-r\left(s_{t^{-}}\right) d t-\eta\left(s_{t^{-}}\right) d Z_{t}^{\Lambda}+\delta_{G}\left(s_{t^{-}}\right)\left(e^{\kappa}-1\right) d M_{t}^{G}-\delta_{B}\left(s_{t^{-}}\right)\left(1-e^{-\kappa}\right) d M_{t}^{B},
$$

with

$$
\delta_{G}(G)=\delta_{B}(B)=1, \quad \delta_{G}(B)=\delta_{B}(G)=0
$$

where $r\left(s_{t}\right)$ is the state-dependent risk free rate, and $\eta\left(s_{t}\right)$ is the market price of risk for the aggregate Brownian shocks $d Z_{t}^{\Lambda}$. The compensated Poisson processes $d M_{t}^{s t}=d N_{t}^{s_{t}}-\pi_{s t}^{\mathbb{P}} d t$ capture the changes of the aggregate state (away from state $s_{t}$ ), while $\kappa$ determines the size of the jump in the discount factor when the aggregate state changes. To capture the notion that state $B$ is a time with high marginal utilities and high risk prices, we set $\eta(B)>\eta(G)$, and set $\kappa>0$ so that $\Lambda_{t}$ jumps up going into a recession and down coming out of a recession.

A firm generates cash flows $y_{t}$, which follow the process

$$
\frac{d y_{t}}{y_{t}}=\mu^{\mathbb{P}}\left(s_{t}\right) d t+\sigma_{\Lambda}\left(s_{t}\right) d Z_{t}^{\Lambda}+\sigma_{f}\left(s_{t}\right) d Z_{t}^{f}
$$

The standard Brownian motion $Z_{t}^{f}$ is independent of $Z_{t}^{\Lambda}$ and is the source of firm-specific cash-flow shocks. The expected growth rate of cash flows is $\mu^{\mathbb{P}}\left(s_{t}\right)$, while $\sigma_{\Lambda}\left(s_{t}\right)$ and $\sigma_{f}\left(s_{t}\right)$ denote the systematic and idiosyncratic conditional volatility of cash flows, respectively. Although a change in the aggregate state $s_{t}$ does not lead to any immediate change in the

\footnotetext{
${ }^{3}$ See Chen (2010) for a general equilibrium model based on the long-run risk model of Bansal and Yaron (2004) that generates the stochastic discount factor of this form.
} 
level of cash flows, it changes the dynamics of $y_{t}$ by altering its conditional growth rate and volatilities.

Valuation is convenient under the risk-neutral probability measure $\mathcal{Q}$. The SDF in (1) implies the risk-neutral dynamics of cash flows:

$$
\frac{d y_{t}}{y_{t}}=\mu\left(s_{t}\right) d t+\sigma\left(s_{t}\right) d Z_{t}
$$

where $Z_{t}$ is a standard Brownian motion under $\mathcal{Q}$. The risk-neutral expected growth rate of cash flows is $\mu\left(s_{t}\right)=\mu^{\mathbb{P}}\left(s_{t}\right)-\sigma_{\Lambda}\left(s_{t}\right) \eta\left(s_{t}\right)$, and $\sigma\left(s_{t}\right)=\sqrt{\sigma_{\Lambda}^{2}\left(s_{t}\right)+\sigma_{f}^{2}\left(s_{t}\right)}$ is total volatility of cash flows. The adjustment for the expected growth rate is quite intuitive. Cash flows are risky if they are negatively correlated with the stochastic discount factor $\left(\sigma_{\Lambda}\left(s_{t}\right) \eta\left(s_{t}\right)>0\right)$. For valuation under $\mathcal{Q}$, we account for the risks of cash flows by lowering the expected growth rate, which has the same effect as adding a risk premium to the discount rate.

In addition to the cash flow process, the risk-neutral transition intensities between the aggregate states are given by $\pi_{G}=e^{\kappa} \pi_{G}^{\mathbb{P}}$ and $\pi_{B}=e^{-\kappa} \pi_{B}^{\mathbb{P}}$. Because $\kappa>0$, the risk-neutral transition intensity from state $G$ to $B$ is higher than the physical intensity, while the riskneutral intensity from state $B$ to $G$ is lower than the physical intensity. Jointly, they imply that the bad state is both more likely to occur and longer lasting under the risk-neutral measure than under the physical measure.

Without any taxes, the value of an unlevered firm, $V(y, s)$, satisfies the following system of ODEs:

$$
r(s) V(y, s)=y+\mu(s) y V_{y}(y, s)+\frac{1}{2} \sigma^{2}(s) y^{2} V_{y y}(y, s)+\pi_{s}\left(V\left(y, s^{c}\right)-V(y, s)\right),
$$

where $s^{c}$ denotes the complement state to state $s$. Its solution is $V(y, s)=v(s) y$, where $\mathbf{v} \equiv(v(G), v(B))^{\prime}$ is given by

$$
\mathbf{v}=\left(\begin{array}{cc}
r(G)-\mu(G)+\pi_{G} & -\pi_{G} \\
-\pi_{B} & r(B)-\mu(B)+\pi_{B}
\end{array}\right)^{-1}\left(\begin{array}{l}
1 \\
1
\end{array}\right) .
$$


This is a generalized Gordon growth formula, which takes into account the state-dependent riskfree rates and risk-neutral expected growth rates, as well as possible future transitions between the states. In the special case of no transition between the states $\left(\pi_{G}=\pi_{B}=0\right)$, Equation (5) reduces to the standard Gordon growth formula $v(s)=(r(s)-\mu(s))^{-1}$.

\subsection{Capital structure}

Firms in our model choose optimal leverage and debt maturity jointly. The optimal leverage is primarily determined by the trade-off between the tax benefits (interest expenses are tax-deductible) and bankruptcy costs of debt. The effective tax rate on corporate income is $\tau$. In bankruptcy, debt-holders recover a fraction $\alpha(s)$ of the firm's unlevered assets while equity-holders receive nothing. For the maturity choice, firms trade off the rollover risk of short-term debt against the costs of illiquidity for long-term debt.

To fully specify a maturity structure, one needs to specify the amount of debt due at different horizons as well as the rollover policy when debt matures. Leland and Toft (1996) and Leland (1998) model static maturity structures: debt is maturing at a constant rate over time, and the average maturity for all existing debt also remains constant. For example, Leland (1998) assumes that debt has no stated maturity but is continuously retired at face value at a constant rate $m$, and that all retired debt is replaced by new debt with identical face value and seniority. This implies that the average maturity of debt outstanding today is $\int_{0}^{\infty} t m e^{-m t} d t=1 / m$. Such a maturity structure rules out the possibility of dynamic adjustment in maturity, which is an important feature in the data (see Figure 1). A uniform maturity structure also rules out "lumpiness", in particular, the possibility of having a large amount of debt retiring in a short period of time. Choi, Hackbarth, and Zechner (2012) find that lumpiness in debt maturity is commonly observed, which could be for the purpose of lowering floatation costs, improving liquidity, or market timing.

We first extend the maturity structure in Leland (1998) by allowing a firm to roll over its retired debt into new debt of different maturity when the state of the economy changes. Specifically, the maturity structure in state $G$ (good times) is the same as in Leland (1998): 
debt is retired at a constant rate $m_{G}$ and replaced by new debt with the same principal value and seniority. When state $B$ (recession) arrives, the maturity trade-off can change, and the firm can choose to replace the retired debt with new debt of a different maturity (still with the same seniority). This new maturity is determined by the rate $\widehat{m}_{B}$ at which the new debt is retired. Thus, the firm will have two types of debt outstanding in state $B$, one with average maturity of $1 / m_{G}$ and the other with average maturity $1 / \widehat{m}_{B}$ (conditional on being in state $B$ ). After $t$ years in state $B$, the instantaneous rate of debt retirement is $R_{B}(t)=m_{G} e^{-m_{G} t}+\widehat{m}_{B}\left(1-e^{-m_{G} t}\right)$. Finally, when the economy moves from state $B$ back to state $G$, the firm swaps all the type- $\widehat{m}_{B}$ debt into type- $m_{G}$ debt.

The time dependence of $R_{B}(t)$ makes the problem less tractable. Instead, we approximate the above dynamics by assuming that all debt will be retired a constant rate $m_{B}$ in state $B$, where $m_{B}$ is the average rate of debt retirement in state $B$ :

$$
m_{B}=\int_{0}^{\infty} \pi_{B}^{\mathbb{P}} e^{-\pi_{B}^{\mathbb{P}} t}\left(\frac{1}{t} \int_{0}^{t} R_{B}(u) d u\right) d t
$$

Thus, choosing $m_{B}$ will be equivalent to choosing $\widehat{m}_{B}$ as long as the value of $\widehat{m}_{B}$ implied by (6) is nonnegative.

Based on this interpretation of maturity dynamics, the choice of capital structure can be characterized by the 4 -tuple $\left(P, C, m_{G}, m_{B}\right)$, where $P$ is the face value of debt and $C$ is the (instantaneous) coupon rate. The default policy, which is chosen by equity-holders ex post, is determined by a pair of default boundaries $\left\{y_{D}(G), y_{D}(B)\right\}$. In a given state, the firm defaults if its cash flow is below the default boundary for that state. As shown in Chen (2010), because the default boundary is different in the two states, default can either be triggered by small shocks that drive the cash flow below the default boundary, or by a change in the state that raises the default boundary above the cash flow.

Longstaff, Mithal, and Neis (2005) use the credit spreads for corporate bonds and credit default swaps to identify the non-default component in bond yields. They find a strong positive relation between corporate bond maturity and the non-default component. He and Milbradt (2012) provide a model that endogenously link the corporate bond liquidity spread 
to maturity. We capture the illiquidity of long-term bonds in reduced form by positing a non-default spread, $\ell\left(m, s_{t}\right)$, at which debt is priced by the market. Specifically, we assume

$$
\ell\left(m, s_{t}\right)=\ell_{0}(s)\left(e^{\ell_{1}(s) / m}-1\right) .
$$

With positive values for $\ell_{0}$ and $\ell_{1}$, the non-default spread will be increasing with maturity (decreasing in $m$ ), and the spread goes to 0 when maturity approaches 0 ( $m$ goes to infinity). In addition, we allow the non-default spread to depend on the aggregate state. In particular, for the same maturity, the spread can be higher in the bad state: $\ell(\cdot, B)>\ell(\cdot, G)$.

The time- $t$ market value of all the debt that is issued at time $0, D^{0}(t, y, s)$, satisfies a system of partial differential equations:

$$
\begin{aligned}
\left(r(s)+\ell\left(m_{s}, s\right)\right) D^{0}(t, y, s)= & e^{-\int_{0}^{t} m_{s u} d u}\left(C+m_{s} P\right)+D_{t}^{0}(t, y, s)+\mu(s) y D_{y}^{0}(t, y, s) \\
& +\frac{1}{2} \sigma^{2}(s) y^{2} D_{y y}^{0}(t, y, s)+\pi_{s}\left(D^{0}\left(t, y, s^{c}\right)-D^{0}(t, y, s)\right)
\end{aligned}
$$

where $e^{-\int_{0}^{t} m_{s_{u}} d u}$ gives the fraction of original debt that has not retired by time $t$. At bankruptcy, the value of these debt will be fraction $e^{-\int_{0}^{t} m_{s_{u}} d u}$ of the total recovery value.

As in Leland (1998), the value of total debt outstanding at time $t, D\left(y_{t}, s_{t}\right)$, will be independent of $t$. It satisfies the following system of ordinary differential equations:

$$
\begin{aligned}
\left(r(s)+\ell\left(m_{s}, s\right)\right) D(y, s)= & C+m_{s}(P-D(y, s))+\mu(s) y D_{y}(y, s) \\
& +\frac{1}{2} \sigma^{2}(s) y^{2} D_{y y}(y, s)+\pi_{s}\left(D\left(y, s^{c}\right)-D(y, s)\right),
\end{aligned}
$$

with boundary condition at default:

$$
D\left(y_{D}(s), s\right)=\alpha(s) v^{*}(s) y_{D}(s)
$$

where $v^{*}(s)$ is the price-to-cash-flow ratio given in (5). Everything else equal, adding the non-default spread lowers the market value of debt, which is a form of financing costs that will affect equity-holders' financing decisions. 
Next, the value of equity, $E(y, s)$, satisfies:

$$
\begin{aligned}
r(s) E(y, s)= & (1-\tau)(y-C)-m_{s}(P-D(y, s))+\mu(s) y E_{y}(y, s) \\
& +\frac{1}{2} \sigma(s)^{2} y^{2} E_{y y}(y, s)+\pi_{s}\left(E\left(y, s^{c}\right)-E(y, s)\right) .
\end{aligned}
$$

For simplicity, we assume that equity is discounted at the riskfree rate $r(s)$, i.e., there is no additional liquidity discount for equity valuation. In practice, corporate bond markets are significantly more illiquid than equity markets.

The first two terms on the right-hand side of equation (11) give the instantaneous net cash flow accruing to equity holders of an ongoing firm. The first part of the net cash flow is the cash flow net of interest expenses and taxes. The second part, $m_{s}(P-D(y, s))$, is the rollover costs. When old bonds mature and are replaced by new bonds that are issued under par value $(D(y, s)<P)$, equity holders will have to incur extra costs for debt rollover.

The rollover costs depend on both firm specific and macroeconomic conditions. A firm with low cash flows $y_{t}$ has more risky debt and will thus incur higher rollover costs. Under poor macroeconomic conditions, low expected growth rates of cash flows, high systematic volatility, and high liquidity spreads all tend to drive the market value of debt lower, which also raises the rollover costs. Finally, a shorter debt maturity means debt is retiring at a higher rate ( $m$ is large), which amplifies the rollover costs whenever debt is priced below par.

The boundary conditions for equity at default are:

$$
\begin{aligned}
E\left(y_{D}(s), s\right) & =0 \\
E_{y}\left(y_{D}(s), s\right) & =0
\end{aligned}
$$

The first condition states that equity value is zero at default. The second is the standard smooth-pasting condition that ensures that the default boundary $y_{D}(s)$ is optimal. We obtain closed-form expressions (up to solving a system of non-linear equations) for equity value. The details of the solution are in the appendix.

The tradeoff between rollover risk and financing costs due to liquidity is influenced by 
leverage, systematic risk exposure, and macroeconomic conditions. All else equal, firms with low leverage or low exposure to systematic risk are less concerned about rollover risk. They will gravitate towards short-term debt to reduce financing costs. The opposite is true for highly levered firms or firms with high systematic risk exposure, who will prefer longer maturity debt despite the liquidity discount. These tradeoffs also vary over the business cycle. For example, rollover risk is more of a concern in recessions because firms are closer to bankruptcy and the costs of bankruptcy are higher during such times.

Having discussed the value of debt and equity given the capital structure in place, we now state the firm's capital structure problem. At time $t=0,{ }^{4}$ the firm takes as given the pricing kernel $\Lambda_{t}$, the cash flow process $y_{t}$, the tax rate $\tau$, bankruptcy costs $\alpha(s)$, and the non-default spreads for corporate bonds $\ell(m, s)$, and chooses its capital structure $\left(P, m_{G}, m_{B}\right)$ in order to maximize the initial value of the firm:

$$
\max _{P, m_{G}, m_{B}} E\left(y_{0}, s_{0} ; P, m_{G}, m_{B}\right)+D\left(y_{0}, s_{0} ; P, m_{G}, m_{B}\right) .
$$

We fix the coupon rate $C$ such that debt is priced at par at issuance. In addition, we have assumed that the firm can commit to its maturity policy $\left(m_{G}, m_{B}\right)$ chosen at time $t=0$. Alternatively, equity-holders can ex post choose when to adjust its debt maturity, which will not only depend on the aggregate state, but also the firm's cash flows.

\subsection{A lumpy maturity structure}

The dynamic maturity adjustment introduced above still does not allow for lumpiness in the maturity structure. In this section, we modify the baseline 2-state model to allow such features. Choi, Hackbarth, and Zechner (2012) analyzes why firms might choose a lumpy maturity structure instead of a granular one. Here we take the lumpy maturity structure as given, and focus on its implication for maturity choice and credit risk.

\footnotetext{
${ }^{4}$ Our model can be extended to have dynamic adjustment in leverage, which have been shown by Strebulaev (2007) and Bhamra, Kuehn, and Strebulaev (2010a) to be important in understanding the time-series and cross-sectional properties of financial leverage.
} 
A basic example of a lumpy maturity structure works as follows. At $t=0$, a firm issues a certain amount of debt with $T$ years to maturity. Each year before $T$ (assuming default has not occurred), the firm makes coupon payments but does not need to pay back any principal. At time $t=T$, all the principal of the debt issued at $t=0$ is paid back, and the firm issues new debt with the same principal and and same maturity $T$ to replace the retired debt. This maturity cycle keeps repeating every $T$ years until default occurs.

The main challenge with capturing such a maturity cycle is that it introduces time dependence, because the maturity of the debt outstanding changes mechanically as time passes. To capture the maturity cycle but avoid the time-dependence problem, we extend the model of Leland (1998) by introducing two maturity states. Again, debt is issued without stated maturity. In the first maturity state, no debt is retired, i.e., $m_{1}=0$. In the second maturity state, $m_{2}=1$, so that the amount of debt rolled over in one year will be equal to the total amount of debt outstanding. Compared to the $T$-year debt above, the first maturity state mimics the time when no debt is retiring, while the second maturity state mimics the time when all the debt retires. We then specify the transition intensities between the two maturity states such that the first state is expected to last for $T-1$ years, while the second state is expected to last for 1 year. ${ }^{5}$

Next, we can also model how the lumpy maturity structure is affected by changes in the state of the aggregate economy. For simplicity, suppose issuing long-term debt becomes so costly in state $B$ that the firm only issues one-year debt in that state. In the aggregate state $G$, the firm follows the above two-state maturity cycle, with the two states denoted by $G_{m=0}$ and $G_{m=1}$. If the state of the economy changes while the firm is in state $G_{m=0}$, it is expected that no debt will be due for $T-1$ years (on average). This state is denoted as $B_{m=0}$. If the state of the economy changes while the firm is in state $G_{m=1}$, all debt effectively has an average maturity of one year and will continue to be rolled into one-year debt, i.e., $m=1$ for as long as the bad state $B$ lasts. We denote this state as $B_{m=1}$. The firm will be stuck in state $B_{m=1}$ until the aggregate state changes back to $G$, at which point we assume the firm

\footnotetext{
${ }^{5}$ There are many other ways to set up the maturity states. For example, we can make the second maturity state more transient and raise $m_{2}$ so that debt is rolled over more quickly. However, one feature this two-state approximation does not capture is the fact that debt maturity decays gradually over time.
} 


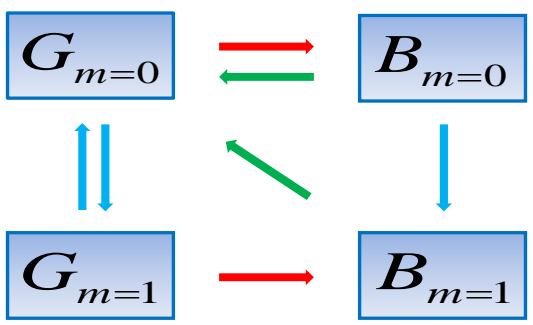

Figure 2: Illustration of the 4-state model. The graph illustrates the state transitions in the 4-state model that allows for lumpiness in the maturity structure.

buys back all the short-term debt and replaces them with new long-term debt. That is, it returns to state $G_{m=0}$. Figure 2 summarizes the dynamics across the maturity states. The transition intensities across the 4 states are given by the generator matrix

$$
\Pi=\left[\begin{array}{cccc}
-\left(\frac{1}{T-1}+\pi_{G}\right) & \frac{1}{T-1} & \pi_{G} & 0 \\
1 & -\left(1+\pi_{G}\right) & 0 & \pi_{G} \\
\pi_{B} & 0 & -\left(\pi_{B}+\frac{1}{T-1}\right) & \frac{1}{T-1} \\
\pi_{B} & 0 & 0 & -\pi_{B}
\end{array}\right]
$$

Details for the solution to the 4-state model are in Appendix A.

\section{Quantitative Analysis}

\subsection{Calibration}

Panel A of Table 1 summarizes the parameter values for our baseline model. The transition intensities for the aggregate states are given by $\pi_{G}^{\mathbb{P}}=0.1$ and $\pi_{G}^{\mathbb{B}}=0.5$, which imply that an expansion state is expected to last for 10 years, while a recession is expected to last for 2 years. The stationary probabilities of being in an expansion and a recession are 5/6 and 1/6, respectively. To calibrate the stochastic discount factor, we calibrate the riskfree rate $r(s)$, the market prices of risk for Brownian shocks $\eta(s)$, and the market price of risk for state 
transition $\kappa$ to match their counterparts in the SDF in Chen (2010). ${ }^{6}$

Similarly, we calibrate the expected growth rate $\mu^{\mathbb{P}}(s)$ and systematic volatility $\sigma_{\Lambda}(s)$ for the benchmark firm based on Chen (2010), which in turn is calibrated to the data of corporate profits from the National Income and Product Accounts. The idiosyncratic cash flow volatility of the benchmark firm is fixed at $\sigma_{f}=23 \%$. The bankruptcy recovery rates in the two states are $\alpha(G)=0.72$ and $\alpha(B)=0.59$. Such cyclical variation in the recovery rate has important effects on the ex ante bankruptcy costs. The effective tax rate $\tau=0.2$, which takes into account the fact that part of the tax advantage of debt at the corporate level is offset by individual tax disadvantages of interest income (see Miller (1977)). Next, the coupon rate is $C / P=5 \%$, which is chosen so that the bond is issued at par for the benchmark firm. To define model-implied market betas, we specify the dividend process for the market portfolio using the levered cash-flow process (2) without idiosyncratic volatility. The leverage factor is chosen so that the unlevered market beta for the benchmark firm is 0.8.

The specification for the non-default term spread $\ell(m, s)$ is given by $(7)$. We calibrate $\ell(m, G)$ based on Longstaff, Mithal, and Neis (2005), who find that increasing the maturity by 1 year raises the non-default spread of corporate bonds by 2 bps on average. The calibrated non-default spreads for a 3-year bond and a 8-year bond are 0.3 bps and 8 bps, respectively. Calibrating $\ell(m, B)$ is more difficult due to the lack of data. We assume the non-default spread is higher in state $B$, with the spreads for a 3-year bond and a 8-year bond rising to 13 bps and 45 bps, respectively.

\subsection{Maturity choice}

The model implications for the benchmark firm are summarized in Panel B of Table 1. We assume that the firm makes its optimal capital structure decision in state $G$. The initial interest coverage $\left(y_{0} / C\right)$ is 2.6 . The initial market leverage is $29.2 \%$ in state $G$. Fixing the level of cash flow, the same amount of debt will imply a market leverage of $32.4 \%$ in state $B$

\footnotetext{
${ }^{6}$ For example, $r(G)$ and $r(B)$ are chosen to match the mean and volatility of the riskfree rate in Chen (2010).
} 
due to the fact that equity value drops more than debt value in recessions. The optimally chosen maturity for state $G$ is 5.5 years, and it drops to 5.0 years for state $B$. Based on the interpretation of maturity adjustment in equation (6), $m_{B}=1 / 5$ corresponds to $\widehat{m}_{B}=0.31$. That means the firm replaces its 5-year debt that retires in state $B$ with new 3.3-year debt. The decline in maturity in state $B$ is the direct result of the higher non-default spread in that state. If we were to hold the non-default spread constant across the two states, the firm will actually prefer longer debt maturity in state $B$ due to higher default risk.

The model-implied 10-year default probability is $4.6 \%$ in state $G$ and $6.0 \%$ in state $B$, while the the 10-year credit spread is 102.6 bps in state $G$ (based on initial leverage) and 141.1 bps in state $B$. These values closely match the historical average default rate and credit spread for Baa-rated firms. Finally, the conditional equity Sharpe ratio is 0.12 in state $G$ and 0.22 in state $B$.

When computing the credit spreads at different maturities, we focus on the default-related component. To do so, we take the firm's optimal default policy as given and simulate under the risk-neutral probability the cash flows for a fictitious bond (with a given maturity) that defaults at the same time as the firm. The bond recovery rate is assumed to be $44 \%$ in state $G$ and $20 \%$ in state $B$, which matches the historical average recovery rate of $41.4 \%$. We then price the cash flows without adding the non-default spread to the riskfree rate.

Next, to study how systematic risk affects firms' maturity structure, we compute the optimal debt maturity for firms with different amount of systematic volatility in cash flows, which are obtained by rescaling the systematic volatility of cash flows $\left(\sigma_{\Lambda}(G), \sigma_{\Lambda}(B)\right)$ for the benchmark firm while keeping the idiosyncratic volatility of cash flows $\sigma_{f}$ unchanged. We first examine the case where leverage is chosen optimally for each firm, and then the case where leverage is held constant across firms.

Figure 3 shows the results. In Panel A, controlling for the idiosyncratic cash-flow volatility, optimal debt maturity in both the expansion and recession state increases for firms with higher systematic volatility. For example, as the average systematic volatility rises from 0.07 to 0.21 , the optimal maturity in state $G$ rises from 5.16 to 5.96 years, whereas the maturity 

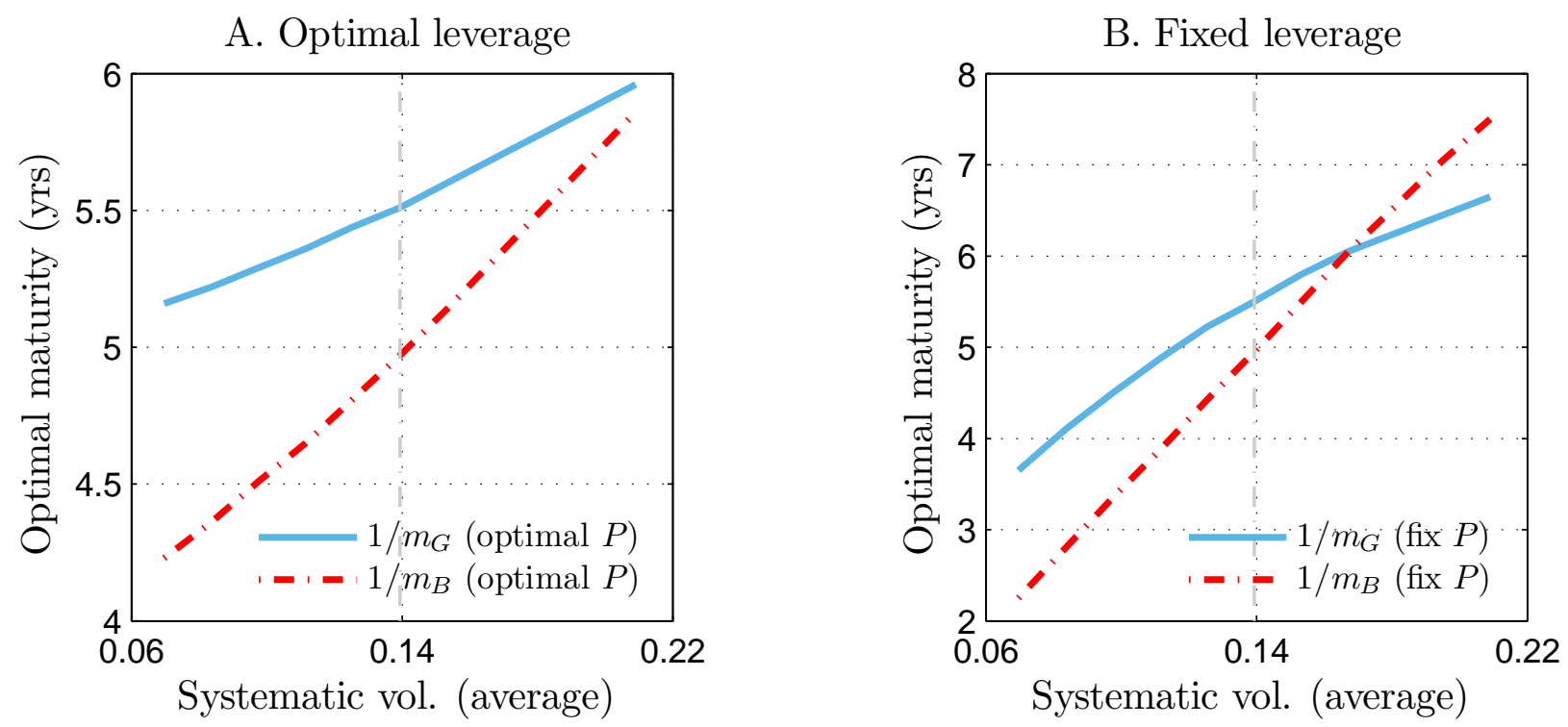

Figure 3: Optimal debt maturity. In Panel A, we hold fixed the idiosyncratic volatility of cash flow while letting the systematic volatility vary and then plot the resulting choices of the optimal average maturity in the two states under optimal leverage. In Panel B, we repeat the exercise but hold leverage fixed at the level of the benchmark firm. The benchmark firm has an average systematic volatility of 0.139 .

in state $B$ rises from 4.23 to 5.86 years. The result is consistent with the intuition that firms with high systematic risk face higher rollover risk and will prefer longer debt maturity, despite the higher non-default spread associated with longer term debt. While the actual speed at which maturity increases with systematic volatility is clearly affected by the calibration of the non-default spread, the qualitative result is robust because the non-default spread in the model is unaffected by firms' systematic volatilities. Based on our calibration, the increase in debt maturity with systematic volatility is faster in a recession than in an expansion. As a result, the debt maturity for firms with high systematic risk changes very little over the business cycle, while that for firms with low systematic risk changes much more.

In Panel B of Figure 3, instead of allowing firms with different systematic risk to choose their leverage optimally, we fix the leverage for all firms at the same level as the benchmark firm, which has average systematic volatility of $13.9 \%$. While the results are qualitatively similar, debt maturity in this case increases faster with systematic volatility in both states. 
For firms with sufficiently high systematic risk exposure, the debt maturity in state $B$ can become even higher than the maturity in state $G$, indicating that these firms roll their maturing debt into longer maturity in recessions.

The reason that optimal debt maturity becomes more sensitive to systematic volatility after controlling for leverage is as follows. Because of higher expected costs of financial distress, firms with high systematic risk exposure will optimally choose lower leverage. By fixing their leverage at the level of the benchmark firm, firms with high systematic volatility end up with higher leverage than the optimal amount. As a result, using long-term debt to reduce rollover risk becomes more important for these firms, especially in bad times.

To gain more intuition on why maturity choice is affected by systematic risk, we examine how the probability of default in different states are affected by maturity choice. Table 2 provides information about the 5-year cumulative default probabilities for firms with different leverage (measured by interest coverage), debt maturity, and asset beta. It is quite intuitive that, all else equal, the default probability is higher for firms with higher leverage or higher beta. Let's now focus on the effect of maturity.

In both state $G$ and $B$, a firm can reduce its default probability by switching from short to long maturity. The effect of maturity change on default probability is bigger for firms with higher beta or higher leverage. In other words, for these firms, the same increase in maturity will have a larger reduction in their bankruptcy costs. Since the costs of long-term debt do not directly depend on beta or leverage, this result will lead firms with higher beta or higher leverage to choose longer maturity.

Next, for the same firm, the probability of default rises in state $B$. This increase is bigger for firms with higher beta or higher leverage, but it is smaller when debt maturity is long. For example, by switching from short to long maturity, a high beta/high leverage firm can reduce the increase in 5-year default probability from $G$ to $B$ by $3.39 \%$, whereas a low beta/high leverage firm only reduces the increase in default probability by $0.84 \%$. This suggests that firms with higher beta or higher leverage will be more reluctant to reduce their maturity going into state $B$. 


\subsection{Maturity and credit risk}

What are the implications of maturity choice for the term structure of credit spreads? ${ }^{7}$ Intuitively, in the presence of financing frictions, the distribution of debt maturity should play a role in determining the probability of default at different horizons. However, a structural model is needed to make more precise predictions about the impact of debt maturity on credit spreads, particularly in light of the connections between systematic risk and debt maturity demonstrated in the previous section.

Specifically, we examine the following questions about debt maturity and credit risk.

1. How much does the pro-cyclical variation in debt maturity amplify the fluctuations in credit spreads over the business cycle?

2. Could the fact that firms with higher systematic risk exposure tend to choose longer debt maturity reverse the prediction that firms with higher rollover risk should be more sensitive to aggregate shocks?

3. How does a lumpy maturity structure affect the term structure of credit spreads differently from a granular maturity structure?

To answer the first question, we conduct the following comparative static exercise. Consider the benchmark firm from Section 3.2. It optimally chooses an initial leverage of $29.2 \%$ (with interest coverage of 2.6) and a debt maturity of 5.5 years in state $G$, but drops the maturity to 5.0 years (on average) in state $B$. To isolate the effects of this maturity reduction in state $B$, we compute the credit spreads in the case where debt maturity is fixed at 5.5 years in both states (which requires solving for a different default policy), and compare them to the credit spreads of the benchmark firm.

Panel A of Figure 4 shows the results. When debt maturity is reduced in state $B$, credit spreads go up in both state $G$ and $B$, but more so in state $B$. This suggests that pro-cyclical debt maturity does amplify the fluctuations in credit spreads over the business cycle. However, quantitatively, the effect of maturity reduction on credit spreads is very small (less than 5

\footnotetext{
${ }^{7}$ All the credit spreads reported in this section refer to the default component of the credit spreads.
} 
A. Low leverage, optimal $m_{B}$

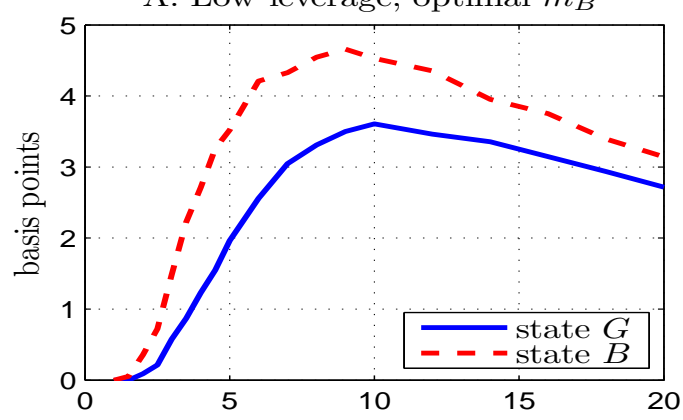

C. High leverage, optimal $m_{B}$

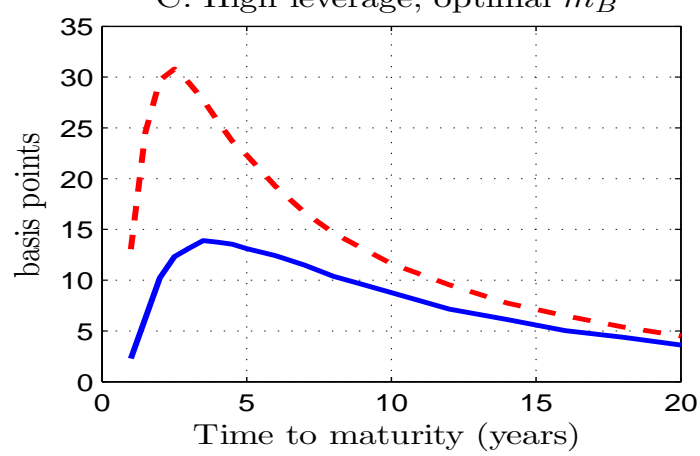

B. Low leverage, $m_{B}=1$

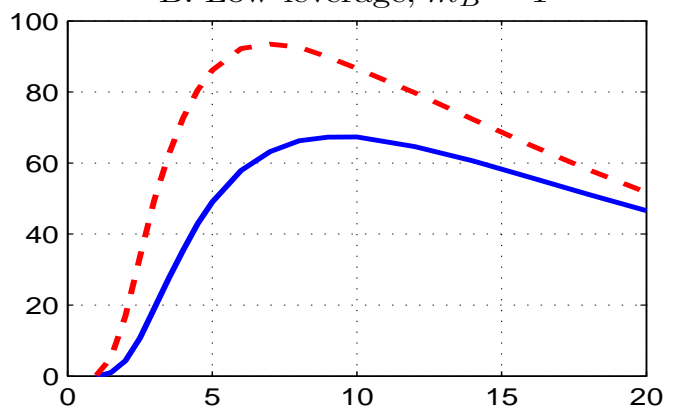

D. High leverage, $m_{B}=1$

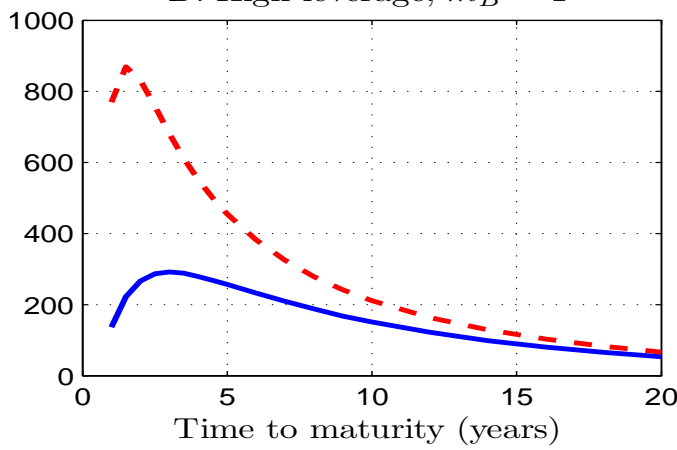

Figure 4: The amplification effect of maturity choice on credit spreads. This figure plots the differences in credit spreads between a firm with constant debt maturity of 5.5 years in state $G$ and $B$ and a firm that has maturity of 5.5 years in state $G$ but shorter maturity in state $B$. Two values for debt maturity in state $B$ are: 5 years (the optimal choice for the benchmark firm) and 1 year. In Panels A and B, the firm's leverage is at the optimal level, with interest coverage of 2.6. In Panels $\mathrm{C}$ and $\mathrm{D}$, the firm's interest coverage is fixed at 1.3.

bps). This is not surprising given the benchmark firm's low leverage and the relatively small difference in debt maturity between state $G$ to $B$.

What could make the debt maturity drop more in state $B$ ? Revisiting the mechanics for how debt maturity is adjusted in Section 2.2, we see that debt maturity will become shorter in state $B$ if the firm rolls the retired debt into new debt with shorter maturity (e.g., due to higher non-default spread for longer-term debt), or if the bad state is more persistent. For illustration, consider the case where the average debt maturity falls from 5.5 years to 1 year on average in state $B$. Based on the interpretation of maturity adjustment in equation (6), $m_{B}=1$ corresponds to $\widehat{m}_{B}=5.7$, or approximately a maturity of 2 months. As Panel B of Figure 4 shows, the maturity effect becomes significantly stronger in this case, with credit 
spreads rising by up to 67 bps in state $G$ and 93 bps in state $B$.

Next, in Panels $\mathrm{C}$ and $\mathrm{D}$, we repeat the exercises above after raising the initial leverage of the benchmark firm (with the interest coverage dropping from 2.6 to 1.3). The cases of high leverage are relevant because even though firms start with optimal low leverage, their leverage can rise substantially over time due to negative cash-flow shocks and the costs associated with downward adjustment in the debt structure. Since we assume firms precommit to their choices of $\left(m_{G}, m_{B}\right)$, we now look at the effects of the same change in debt maturity as in Panels A and B when the firm's leverage has risen.

Not surprisingly, the maturity effect on credit spreads is stronger for a high-leverage firm. Even when the maturity only drops from 5.5 years to 5.0 years, the credit spread can rise by up to $13 \mathrm{bps}$ in state $G$ and $31 \mathrm{bps}$ in state $B$. For a large reduction in maturity, the spread can rise by up to 290 bps in state $G$ and 870 bps in state $B$. More interestingly, the largest increases in credit spreads due to the maturity reduction are now concentrated at the short end of the credit curve (1-3 years) instead of the middle part (7-10 years) in the case of low leverage.

The intuition is the following. With low leverage, the firm faces low default risk. In this case, especially in the near future, newly issued debt will be priced close to par value, and more frequent rollover (even when $m_{B}=1$ ) will not raise the burden for equity holders (see (11)). This is why the increase in credit spreads is negligible at the short end of the credit curve. Over time, due to the volatility of cash flows, financial distress becomes more likely with the passage of time, and the maturity effect shows up. But at even longer horizon, the firm's cash flows are expected to grow, which can dominate the effect of volatility at sufficiently long horizons. This causes the maturity effect to weaken eventually. In contrast, the impact of shorter maturity on default risk immediately shows up in the case of high leverage, because the newly issued bonds are priced under par already. Over time, the maturity effect is reduced because of the expected growth in cash flows and the fact that maturity will lengthen once the economy leaves the bad state.

Next, we investigate how endogenous maturity choice affects the rollover risk. The 

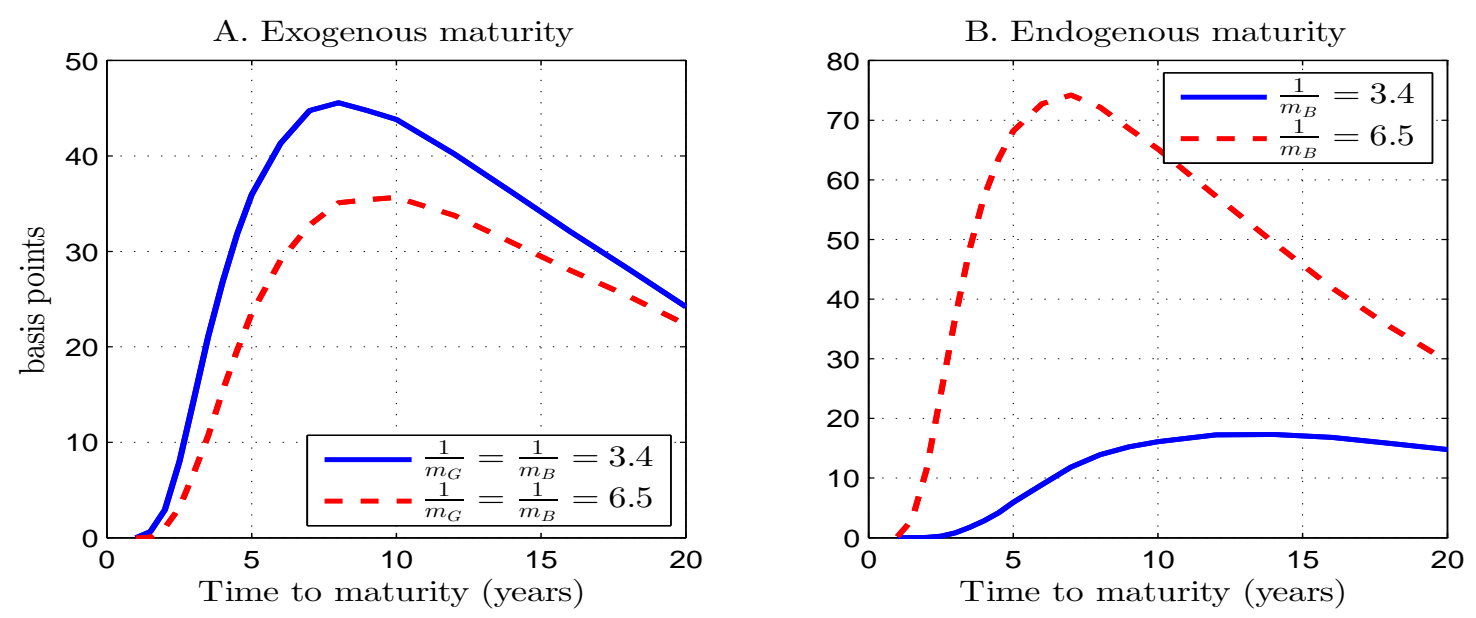

Figure 5: Credit spread changes under exogenous vs. endogenous maturity choice. This figure plots the increase in credit spreads when the aggregate state switches from $G$ to $B$ for different firms. In Panel A, the two firms have the same systematic risk exposure but are given different debt maturity choice exogenously. In Panel B, the two firms endogenously choose different maturity structure due to differences in systematic risk.

standard notion of rollover risk suggests that shorter maturity leads to stronger reaction of credit spreads to aggregate shocks. The opposite can be true when maturity choice is endogenous. As our model shows, firms with longer maturity tend to have higher beta, especially in bad times. Since high beta causes the firm to become more sensitive to aggregate shocks, it could offset and even reverse the effects of rollover risk.

We illustrate this point in Figure 5. In Panel A, we take two firms with identical asset beta (the same as the benchmark firm), but fix their debt maturity exogenously at 6.5 years and 3.4 years, respectively. Notice that we not only ignore the endogeneity of maturity choice in this case, but also prevent the maturity to change across the states. In Panel B, we identify two firms with different systematic volatility (but the same average total volatility), which leads them to choose different debt maturities endogenously. One firm has an average systematic volatility of $18.9 \%$ and sets its debt maturity in state $B$ optimally at 6.5 years. The other has an average systematic volatility of $8.9 \%$ and sets its maturity in state $B$ at 3.4 years. The leverage for all the firms are fixed at the same level as the benchmark firm. The figure plots the differences in credit spreads between state $B$ and state $G$ for different 
horizons, which measures the response of the credit spreads to the aggregate shock.

Panel A shows that, with exogenous maturity, the credit spread rises more for the firm with shorter maturity, which is consistent with the standard intuition of rollover risk. In Panel B, however, the firm with longer maturity actually has a much bigger increase in credit spreads than the one with shorter maturity because of its larger exposure to systematic risk.

The third question we study is about the lumpiness of maturity structure. How would the maturity effect change if the firm issues debt with the same maturity as before, but has all the debt retiring in a short period of time rather than at a constant rate? We use the lumpy maturity model developed in Section 2.3 to study this question. Specifically, we assume that the benchmark firm picks the same maturity of $T_{G}=5.5$ years in state $G$. However, instead of having debt retired at the rate of $m_{G}=1 / 5.5$, we assume that all the debt will (in expectation) retire in their last year to maturity. In addition, we assume that the firm is forced to roll over maturing debt into one-year debt in state $B$. These maturity dynamics are approximated by the 4-state model. We again consider two levels of financial leverage, one with initial interest coverage of 2.6 (the same as the benchmark firm), the other with interest coverage of 1.3 (high leverage).

Figure 6 reports the results. The left panels are based on the results for the low-leverage firm (with the same interest coverage of 2.6 as the the benchmark firm). Panel A shows the full term structure of credit spreads. The term structure is mostly upward sloping. Controlling for maturity, credit spreads are the highest in state $B_{m=1}$, where the aggregate economic conditions are bad and a large amount of debt is due, and lowest in state $G_{m=0}$, where the aggregate economic conditions are good and no debt is due.

For the low-leverage firm, a larger part of the differences in the credit spreads across the 4 states are due to differences in the macroeconomic conditions instead of the maturity states. To see this, compare Panel $\mathrm{C}$, which plots the differences in credit spreads across the two aggregate states (holding the maturity state fixed), and Panel E, which plots the differences in credit spreads across the two maturity states (holding the aggregate state fixed). Credit spreads rise by up to $51 \mathrm{bps}$ if the aggregate state changes at a time when no debt is due 
A. Term structure: low leverage
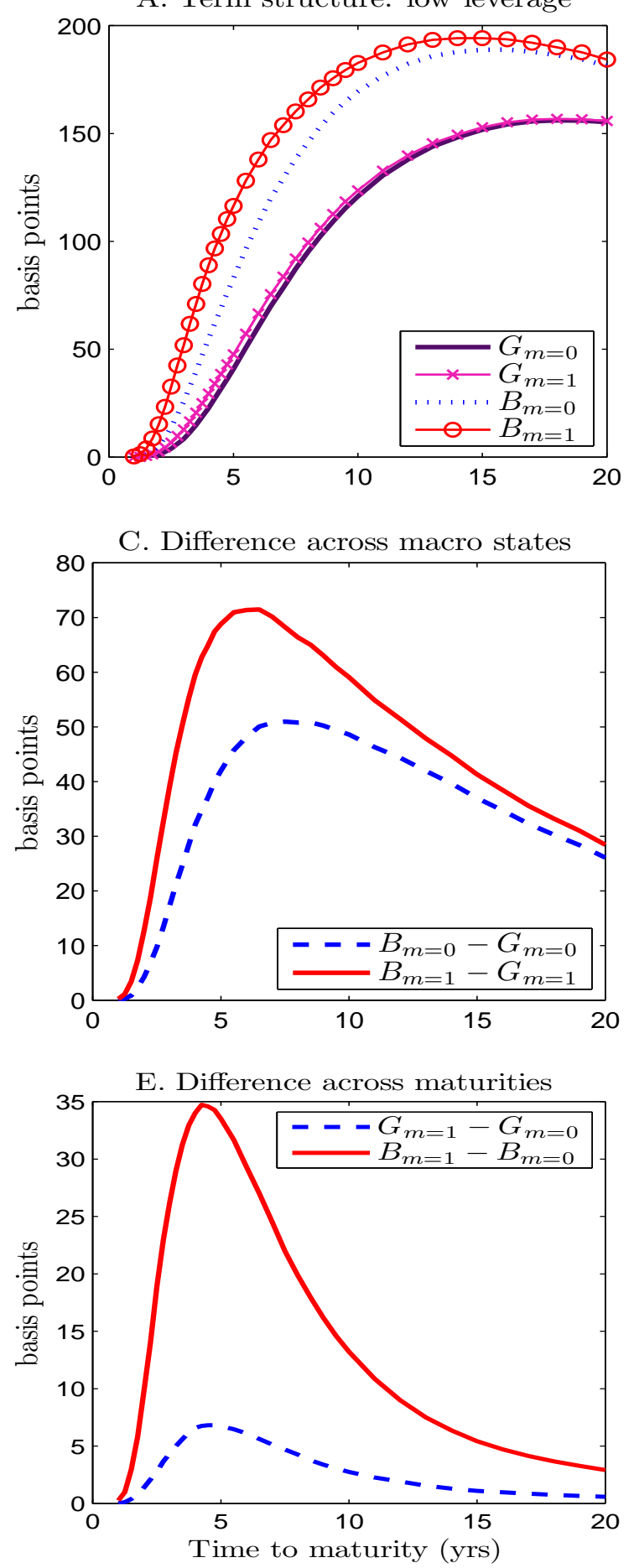

B. Term structure: high leverage
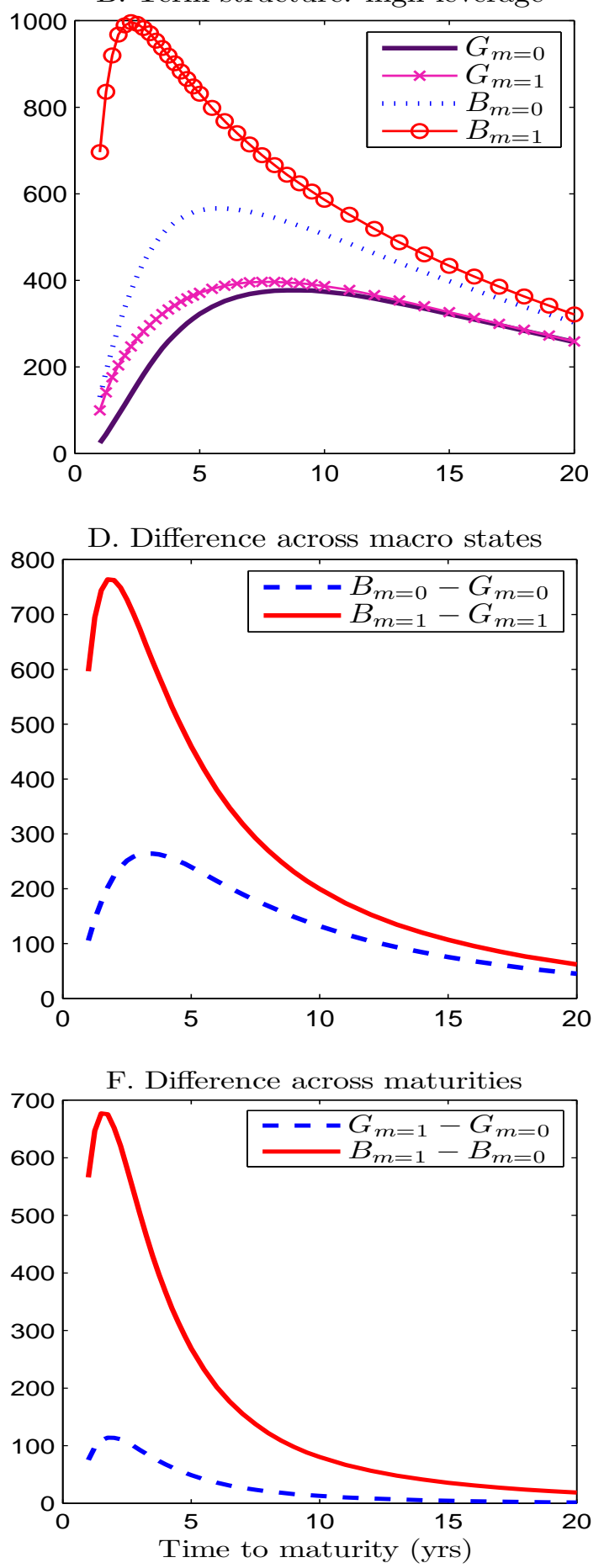

Figure 6: Credit spreads for a lumpy maturity structure. This figure plots the term structure of credit spreads in the model of lumpy maturity structure. The left columns (Panels A, $\mathrm{C}, \mathrm{E}$ ) are for a low-leverage firm (with interest coverage of 2.6). The right columns (Panels B, D, F) are for a high-leverage firm (with interest coverage of 1.3). 
immediately, and by up to 71 bps when the aggregate state changes just as a large amount of debt is coming due. Next, conditional on being in state $G$, whether there is a large amount of debt due soon or not has very little impact on the credit spreads (up to $7 \mathrm{bps}$ ), but the difference becomes more significant in state $B$ (up to $35 \mathrm{bps).} \mathrm{The} \mathrm{biggest} \mathrm{increases} \mathrm{in} \mathrm{credit}$ spread are at 5-8 year maturity. For maturity of 2 years or less, neither a change in the aggregate state or the maturity state has any sizable impact on the credit spreads.

When the firm has high leverage, its credit spreads rise more following a bad aggregate shock, especially when the aggregate shock arrives when a large amount of debt is due. As Panel D shows, the rise in credit spreads can be as high as 260 bps when no debt is due immediately, vs. 760 bps when a large amount of debt is due soon. Unlike in the case of low leverage ratio, lumpiness in the maturity structure now has a much larger effect on the credit spreads, especially when the aggregate economic condition is poor. In Panel F, credit spreads can rise by up to 110 bps in state $G$ and up to 680 bps in state $B$ due to the fact that a large amount of debt needs to be rolled over soon. The biggest increases in credit spread are now at 1-3 year maturity, and the effects are rapidly reduced as maturity lengthens.

Finally, the interaction between rollover risk and debt maturity has interesting implications

for empirically observed credit spreads (not just the default component). On the one hand, longer maturities decrease credit spreads by lowering default probabilities; on the other hand, longer maturities increase credit spreads by increasing the liquidity spread. This illustrates the difficulty in decomposing credit spreads into default and liquidity components: capital structure and default decisions depend both on firm fundamentals as well as liquidity in the corporate bond market, which makes credit risk and market liquidity interdependent.

\section{Empirical Evidence}

In this section, we test the model implications about the link between systematic risk and debt maturity both in the cross section of firms and in the time series. 


\subsection{Data}

To empirically test our model's implications, we merge the data from COMPUSTAT annual industrial files and the Center for Research in Securities Prices (CRSP) files for the period 1974 to 2010. ${ }^{8}$ We exclude financial firms (SIC codes 6000-6999), utilities (SIC codes 4900-4999), and quasi-public firms (SIC codes greater than 8999), whose capital structure decisions can be subject to regulation. In addition, we require firms in our sample to have total debt that represents at least $5 \%$ of their assets. ${ }^{9}$ All the variables are winsorized at the $1 \%$ and $99 \%$ level. Finally, we remove firm-year observations with extreme year-to-year changes in the capital structure (defined as having changes in book leverage or long-term debt share in the lowest or highest 1\%), which are likely due to major corporate events such as mergers, acquisitions, and spin-offs.

Following previous studies on the determinants of debt maturity (see Barclay and Smith (1995), Guedes and Opler (1996), and Stohs and Mauer (1996)), we construct our benchmark measure of debt maturity using the long-term debt share, which is the percentage of total debt obligations that are due in more than 3 years (ldebt $3 y)$. For robustness, we also measure long-term debt share using the percentage of total debt due in more than $n$ years (ldebtny), with $n=1,2,4,5$. For each firm, COMPUSTAT provides information on the amount of debt in 6 maturity categories: debt due in less than 1 year $(d l c)$, debt due in years two to five $(d d 2, d d 3, d d 4$, and $d d 5)$, and debt due in more than 5 years. This information allows us to construct the above measures of debt maturity. In addition to the long-term debt share, we also construct a book-value weighted numerical estimate of debt maturity (debtmat) by assuming that the average maturity of the 6 COMPUSTAT maturity categories is 0.5 year, 1.5 years, 2.5 years, 3.5 years, 4.5 years, and 10 years, respectively.

Our primary measure of firms' exposure to systematic risk is the asset market beta. Since firm asset value is not directly observable, we follow Bharath and Shumway (2008) and back out asset betas from equity betas based on the Merton (1974) model (details of the procedure

\footnotetext{
${ }^{8} 1974$ is the first year in which COMPUSTAT begins to report balance sheet information used to construct our proxies for debt maturity.

${ }^{9}$ Choosing a different threshold of $3 \%$ generates very similar results.
} 
are in Appendix B). Equity betas are computed using past 36 months of equity returns and value-weighted market returns. In this process, we also obtain the Merton distance-todefault measure (mertondd), which is a proxy for firms' default probability, the firms' total asset volatility (assetvol), as well as the systematic and idiosyncratic asset volatilities (sys assetvol and id assetvol). Moreover, following Acharya, Almeida, and Campello (2010), we also compute the "asset bank beta," which is based on the firm's exposure to a banking sector portfolio, and the "asset tail beta," which captures the firm's exposure to large negative shocks to the market portfolio.

The asset betas above are all computed by de-levering equity betas using the Merton model. A firm's leverage decision is potentially related to its debt maturity decision. Consequently, the various asset betas could be related to debt maturity mechanically through leverage. We address this concern with two additional measures of systematic risk exposure. First, we compute firms' cash flow betas using rolling 20-year windows. The cash flow beta is defined as the covariance between firm-level and aggregate cash flow changes (normalized by total assets from the previous year) divided by the variance of aggregate cash flow changes. Second, Gomes, Kogan, and Yogo (2009) show that demand for durable goods is more cyclical than that for nondurable goods and services. As a result, cash flows of durable-good producers are exposed to higher systematic risk than those for non-durable good and service producers. They classify industries into three groups according to durability of a firm's output. We use their classifications as an alternative measure of systematic risk exposure.

Finally, previous empirical studies have found that debt maturity decisions are related to several firm characteristics, including firm size (log market assets, or mkat), abnormal earnings (abnearn), ${ }^{10}$ book leverage (bklev), market-to-book ratio $(m k 2 b k)$, profit volatility (profitvol), asset maturity (assetmat), and default likelihood. We control for these firm characteristics in our main regressions.

Table 3 provides the summary statistics for variables used in our paper. The median firm has $85 \%$ of their debt due in more than 1 year, $58 \%$ of their debt due in more than

\footnotetext{
${ }^{10}$ Following Barclay and Smith (1995), we define "abnormal earnings" as the change in earnings from year $t$ to $t+1$ normalized by market equity at the end of year $t$.
} 
3 years, and $32 \%$ of their debt due in more than 5 years. There is also considerable cross sectional variation in all three measures. For example, the standard deviation of ldebt3y (the percentage of debt due in more than 3 years) is $32 \%$, and the interquartile range of ldebt $3 y$ is from $27 \%$ to $79 \%$. Based on our numerical measure of debt maturity, the median debt maturity is 4.7 years, with a standard deviation of 2.6 years. The interquartile range of the debt maturity is from 2.5 years to 6.8 years. The median firm in our sample has book leverage of about $27 \%$. The median asset market beta is 0.80 , whereas the median equity beta is 1.07. The median systematic asset volatility is $12 \%$, while the idiosyncratic asset volatility is $30 \%$.

The correlations among the different beta measures are reported in Table 3. We also include other risk measures including assetvol, and Merton's distance-to-default measure (mertondd), which is a proxy for default risk. The various beta proxies are positively correlated. They are also positively correlated with both the systematic and idiosyncratic components of asset volatility. As expected, Merton's distance-to-default measure is negatively correlated with idiosyncratic asset volatility. But its correlation with asset betas is much smaller, probably reflecting the fact that high beta firms choose low leverage to reduce default probability.

\subsection{Debt maturity}

\subsubsection{Cross section of debt maturity}

To take a first look at the model's cross-sectional prediction on the relation between debt maturity and firms' systematic risk exposures, we use the Fama-MacBeth procedure, and regress long-term debt share on systematic and idiosyncratic asset volatility (estimated using rolling 3-year regressions based on the CAPM model), controlling for book leverage. Figure 7 plots the time series of the coefficients on the systematic and idiosyncratic volatilities and their

95\% confidence intervals, which are computed using heteroscedasticity consistent standard errors.

The estimated coefficient for the systematic asset volatility in Panel A is significantly positive for the majority of the sample years, and significantly positive for the overall 
A. F-M coefficient for systematic asset vol

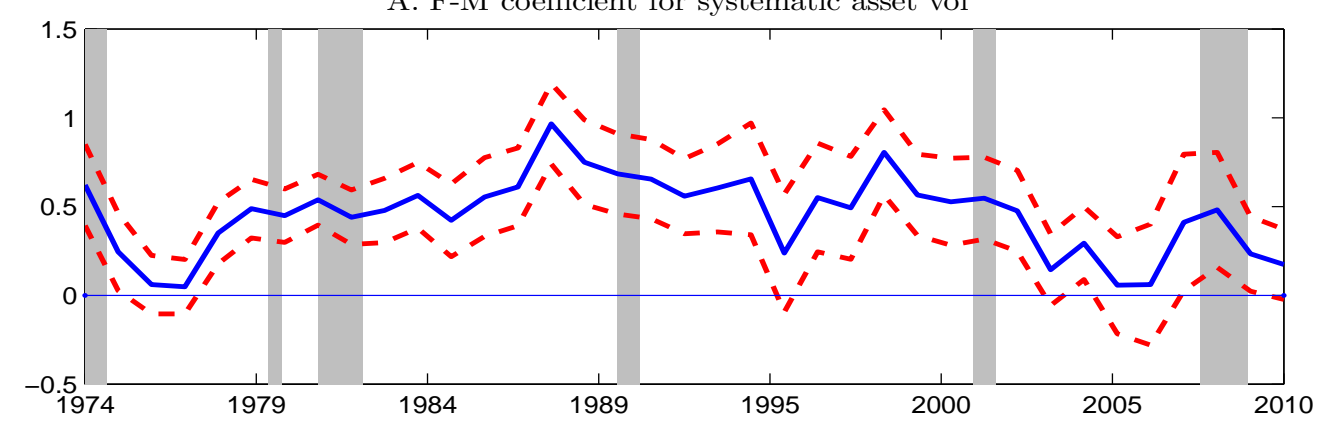

B. F-M coefficient for idiosyncratic asset vol

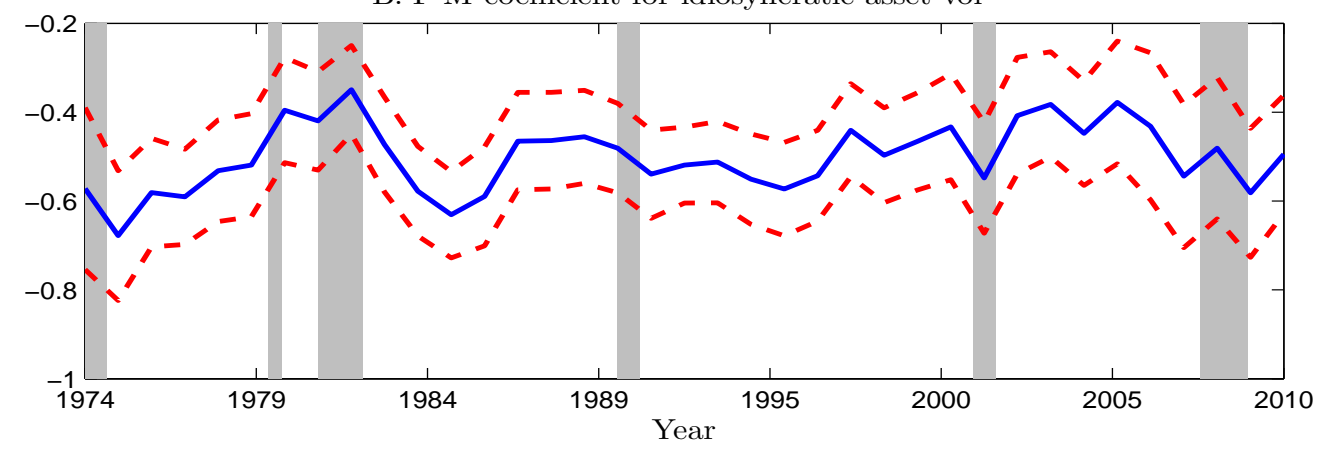

Figure 7: Time series of Fama-MacBeth coefficients for systematic and idiosyncratic volatility. This graph plots time series of coefficient estimates in a cross-sectional regression of long-term debt shares on systematic and idiosyncratic asset volatility. The confidence intervals are at 95\% level. The shaded areas denote NBER-dated recessions.

sample. Two exceptions are the late 1970s and the mid-2000s, when the coefficient becomes insignificant. These results support the model's prediction that, on average, firms with larger exposure to systematic risk have more long-term debt. In contrast, Panel B shows that the coefficient on the idiosyncratic asset volatility is significantly negative throughout the sample, implying that firms with high idiosyncratic risk have shorter maturity.

Earlier studies by Barclay and Smith (1995) and Stohs and Mauer (1996)) have documented a negative relation between debt maturity and measures of firm volatility (such as the volatility of asset returns and earnings changes). Our results suggest that this negative relation is driven by the negative relation between debt maturity and idiosyncratic volatility. which is consistent with the theory of debt maturity based on information asymmetries. As Flannery (1986) and Diamond (1991) point out, issuing short-term debt can be a credible signal for 
firm quality. Since the problem of asymmetric information is more naturally associated with firm-specific uncertainty - managers are unlikely to have more information about the market than outside investors, firms with higher idiosyncratic risk can be treated as having worse quality when issuing long-term bonds, and will have to offer a higher yield as a result.

The average estimated coefficient of the systematic asset volatility is 0.45 . To derive a better understanding of the economic significance of the result, we calculate the impact of moving from the 10th to the 90th percentile for the systematic asset volatility in our sample. The average estimated coefficient implies that this move increases the fraction of long-term debt by $10.4 \%$.

In the following analysis, we investigate these patterns in more detail. We first run crosssectional regressions using the Fama-MacBeth method following the empirical specifications in Barclay and Smith (1995), Guedes and Opler (1996), and Stohs and Mauer (1996). The general specification is as follows:

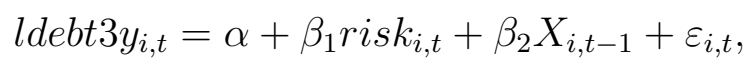

where we use ldebt3y, the share of long-term debt with maturities of 3 years or more, as the proxy for debt maturity; risk $_{i, t}$ represents various measures of firms' systematic risk exposure; $X_{i, t}$ represents firm-specific controls, including total asset volatility (assetvol), market assets (mkat), abnormal earnings (abnearn), book leverage (bklev), market-to-book ratio ( $m k 2 b k)$, asset maturity (assetmat), and profit volatility (profitvol).

The regression results are presented in columns (1) - (8) of Table 4. We compute robust t-statistics using Newey and West (1987) standard errors with 2 lags, except in the case of cash flow beta, where we use 10 lags. Column (9) reports the cross-sectional regression of long-term debt shares on the durability measure suggested by Gomes, Kogan, and Yogo (2009). This measure is fixed over time, so we regress each firm's average long-term debt share on the durability measure and averages of other firm controls.

The coefficient of the asset market beta in column (1) is positive but insignificant in the univariate regression. After controlling for asset volatility, asset market beta becomes 
significantly positively correlated with debt maturity (column (2)). The coefficient estimate of 0.084 implies that a one-standard deviation increase in asset beta, keeping total asset volatility constant, is associated with a $5.4 \%$ increase in the fraction of long-term debt. The effect of asset beta on debt maturity further strengthens to 0.103 after controlling for book leverage (column (3)), which implies that a one-standard deviation increase in asset beta is associated with $6.5 \%$ increase in firms' long-term debt share. The coefficient estimate on asset volatility is negative and statistically significant, which is consistent with Barclay and Smith (1995), Guedes and Opler (1996), and Stohs and Mauer (1996).

Asset volatility consists of systematic and idiosyncratic volatility. In the cross section, holding asset beta fixed while changing total asset volatility is equivalent to holding systematic volatility fixed while increasing idiosyncratic volatility. Thus, the negative effect of asset volatility on debt maturity is driven by the negative relation between idiosyncratic volatility and maturity as shown in Figure 7. It is also intuitive that controlling for asset volatility is key to finding a significant effect for asset beta. Firms with high asset beta will tend to have higher idiosyncratic volatility, which offsets the effect of systematic volatility on debt maturity.

Why is the impact of asset beta on debt maturity even stronger when controlling for leverage? Chen (2010) argues that firms with higher systematic risk exposure are more likely to default in aggregate bad times, which raises the expected costs of bankruptcy. This leads them to choose lower leverage. To the extent that systematic risk affects maturity choice through the default risk channel, a lower leverage will reduce default risk and weaken the relation between asset beta and maturity. Controlling for book leverage addresses this issue. In addition, holding book leverage fixed means that changes in asset beta does not come from the mechanical relation between asset beta and leverage (we obtain asset beta by unlevering equity beta).

Evidence of the opposite effects of systematic and idiosyncratic asset volatility on longterm debt share is presented again in column (4). In column (5), we introduce other firm controls in the model. The coefficient estimate of the asset market beta is 0.048 , smaller 
than the previous specifications although still highly significant. This could be due to the fact that firm characteristics such as size and book-to-market ratio also proxy for systematic risk exposure. The coefficient on asset volatility becomes much smaller than before, which is because firm controls such as size and profit volatility are highly correlated with idiosyncratic asset volatility.

Columns (6) - (8) report regression results when we replace asset market beta with asset bank beta, asset tail beta, and cash flow beta, respectively. These results suggest that our finding of a significantly positive relation between systematic risk and debt maturity is robust to various measures of systematic risk. The coefficient estimates of asset bank beta, asset tail beta, and cash flow beta are 0.051, 0.042, and 0.008 respectively. These estimates imply that a one-standard deviation increase in a firm's corresponding beta measures lengthens its long-term debt share by $2.3 \%, 2.5 \%$, and $2.1 \%$, respectively.

Column (9) reports the cross-sectional regression results when we use the industry classification for producers of durable goods, nondurable goods, and services as proxy for systematic risk exposure. The results show that the long-term debt share of durable good producers, which have more cyclical cash flows, is $2.0 \%$ larger than that of non-durable good producers, and $3.4 \%$ larger than that of service producers.

Table 5 reports the results for pooled regressions, where we add year dummies to absorb time-specific effects, and industry dummies (3-digit SIC code) to control for industry fixedeffects. We adjust our standard errors by clustering the observations at the industry level. ${ }^{11}$ The results are quantitatively similar for various systematic risk measures. Both FamaMacBeth and pooled regression results support our model's implication that systematic risk exposure increases firms' debt maturity. In addition, the evidence suggests that idiosyncratic risk exposure is negatively correlated with debt maturity.

Besides systematic risk measures, the effects of various other firm characteristics on maturity are largely consistent with earlier studies. Everything else equal, firms with low total asset volatility, large size, high leverage, low market-to-book ratio, long asset maturity,

\footnotetext{
${ }^{11}$ We obtain very similar results adjusting standard errors by clustering the observations in the same industry and in the same year.
} 
and low profit volatility are more likely to have longer debt maturity.

\subsubsection{Impact of Business Cycles}

Having examined the cross sectional relation between systematic risk and debt maturity, we now test our model's time series implication by studying the impact of business cycles on debt maturity.

As a proxy for macroeconomic conditions, we obtain recession/expansion dates from the National Bureau of Economic Research (NBER). Since firms differ in their fiscal year-ends, we construct for each firm a yearly recession dummy which equals one if the fiscal year-end month for the firm falls into an NBER-dated recession, and zero otherwise. The results are quantitatively similar if we categorize a fiscal year as in recession when at least three months of the fiscal year are in recession. Then, we examine the impact of business cycles on debt maturity by adding a recession dummy and the interaction term between the recession dummy and asset beta to equation (16).

To measure the changes in debt maturity over the business cycle, we need to remove the time variation in maturity due to secular trends. As shown in Figure 1, the trend component of aggregate debt maturity is U-shaped over the sample period. We include a quadratic deterministic time trend to control for this effect. We assume that the loadings on the time trend are the same for all firms. As a robustness check, we also allow the loadings on the time trend to depend on firm characteristics. The results are presented in Table 6. In short, the results are consistent with the model's prediction that firms shorten their debt maturity in recessions, and the reduction in maturity is larger for firms with lower asset betas.

In column (1), long-term debt share is regressed on the recession dummy, asset market beta, and their interaction term. Column (2) adds asset volatility and book leverage. Column (3) adds all other firm controls. The effects of the recession dummy are similar in the two cases. With firm controls, the coefficient estimate of the recession dummy is -0.042 , while the coefficient of the interaction term between asset market beta and the recession dummy is 0.026. Taken together, these values imply that (a) the long-term debt share of an average 
firm drops by about 1.9\% from expansions to recessions (based on the average market beta of 0.879), which is consistent with the plotted cyclical component of the aggregate long-term debt share in Figure 1; (b) for a firm with an asset market beta at the 10th percentile, its long-term debt share is $3.7 \%$ lower from expansions to recessions, whereas the long-term debt share of a firm with asset market beta at the 90th percentile is essentially unchanged from expansions to recessions. In column (4), replacing the quadratic time trend with the trend component from the Hodrick-Prescott filter generates very similar results.

The regression results using asset bank betas and tail betas are reported in columns (5) - (6). The coefficient estimates of the interaction term between the asset bank beta and the recession dummy, and the interaction term between the asset tail beta and the recession dummy are all positive and statistically significant across different specifications. The economic significance of the coefficient estimates are comparable to those obtained using the asset market beta to measure firms' exposure to systematic risk. The relation between long-term debt shares and abnormal earnings is not significant in the cross-sectional regressions, while it becomes negative and statistically significant in the panel regressions. It is consistent with the hypothesis that firms issue less-information sensitive short-term debt when they have positive information about firms' future earnings. However, the economic significance of the coefficient estimates of abnormal earnings is low.

In the analysis presented so far, we allow the impact of business cycles on debt maturity to depend only on firms' exposure to systematic risk. However, changes in macroeconomic conditions could also affect the relation between debt maturity and other firm characteristics. We find that, in addition to low beta firms, firms with large size and low default probability reduce their debt maturity more from expansions to recessions. This is consistent with the finding of Mian and Santos (2011) that credit worthy firms are more likely not to rollover their long-term debt in bad times. As Table 3 shows, these characteristics are different from our systematic risk measures. On the other hand, we also find that firms with high book leverage reduce maturity more in recessions. This is consistent with Diamond (1991) in that firms with very low credit quality might only be able to issue short-term debt in bad times. The details of these analyses are in Table A.1 of Appendix C. Other robustness 
checks in Appendix $\mathrm{C}$ include the regression results for alternative measures of debt maturity (Table A.2), and for the sample period excluding the recent financial crisis (Table A.3).

A key question remains: how do firms actually reduce debt maturity in bad times? One possibility is that firms do not rollover the long-term debt that matures during a recession. This would imply that total amount of debt declines in recessions. Another possibility is that firms replace maturing long-term debt with short-term debt. As a result, the total amount of debt is largely unchanged. Mian and Santos (2011) show that credit worthy firms do exactly this: instead of rolling over long-term debt in bad times, they draw down on the lines of credit commitment. Our evidence: (1) book leverage has very small difference between expansions and recessions across firms sorted on beta; (2) cross sectional correlation between changes in debt maturity and changes in book leverage is mostly insignificantly different from zero. These results guide our modeling of debt maturity in Section 2.

\subsection{Term structure of credit spreads}

In this section, we empirically test our model's predictions of the effect of debt maturity on the term structure of credit spreads. Specifically, we use the 2008 financial crisis/recession as a proxy for a significant change in macroeconomic conditions and examine the changes in credit spreads for firms with different debt maturity structure entering into the crisis.

We obtain firm-level credit default swap (CDS) spreads with maturity 1 year, 5 years, and 10 years from Markit, and match the data with COMPUSTAT information. Changes in the CDS spreads during the crisis are measured as the differences in the averages of daily CDS spreads from fiscal year 2007 and 2008. Next, we use the 2007 fiscal year balance sheet information to compute the proportion of long-term debt that matures in 2008 $($ ldebt $08=d d 1 /(d d 1+d l t t))$. The larger this measure, the higher rollover risk a firm has to face in the crisis, and the more its debt maturity could potentially be reduced. We follow Almeida, Campello, Laranjeira, and Weisbenner (2011) and treat August 2007 as the onset of the financial crisis. To ensure that the fiscal year 2008 of a firm starts within the crisis, we focus on firms that have the 2007 fiscal year-end months in September, October, November, 
December, or January. The sample of firms with these fiscal year-end months corresponds to $87 \%$ of the 375 firms with CDS data in both fiscal year 2007 and 2008.

We then examine the cross sectional relation between the changes in the CDS spreads from 2007 to 2008 (using the CDS spreads with maturity 1 year, 5 years, and 10 years respectively) and firm's long-term debt structure in 2007. The financial crisis could exacerbate default risk through other firm characteristics. Consequently, we also include other firm characteristics measured in 2007, including market leverage, asset volatility, firm size, market-to-book ratio, profitability, tangibility, equity return (past 12 months), credit rating (from the Standard \& Poor's), and industry dummies (1-digit SIC code) in the regression. ${ }^{12}$

Our model predicts that a larger reduction in debt maturity leads to more significant increases in credit spreads in the crisis. For firms with lumpy maturity structure, those who happen to have a large amount of debt due in a crisis will also have larger increases in credit risk. Both predictions suggest a positive relation between the maturity measure ldebt08 and changes in credit spreads during the crisis. In addition, our model predicts that the maturity effect on credit spreads is more pronounced for firms with high leverage or high systematic risk exposure. To test these additional predictions, we split firms into two groups by dividing the sample at the median of pre-crisis market leverage, book leverage, and cash flow beta, respectively. We then run the regression for firms in each group separately. The regression results are presented in Table 7 . To clearly illustrate the impact of debt maturity on credit spreads and its dependence on leverage and systematic risk exposure, we use the coefficient estimates to compute the implied impact of a one-standard deviation increase in ldebt08 on changes in the CDS spreads, and present the results in Figure 8.

The results show that a firm with a larger portion of its long-term debt maturing in 2008 experiences a more significant increase in CDS spreads. A one-standard deviation increase in ldebt08, which equals $11.2 \%$, at the end of the fiscal year 2007 leads to a $50 \mathrm{bps}, 40 \mathrm{bps}$ and 32 bps increase in the CDS spreads with maturity 1 year, 5 years, and 10 years respectively

\footnotetext{
${ }^{12}$ We convert the credit rating into a numerical scale as follows: 1-AAA+, 2-AAA, 3-AA+, 4-AA, 5-AA-, 6-A+, 7-A, 8-A-, 9-BBB+, 10-BBB, 11-BBB-, 12-BB+, 13-BB, 14-BB-, 15-B+, 16-B, 17-B-, 18-CCC+, 19-CCC, 20-CCC-, 21-CC, and 22-C.
} 
A. Book leverage-sorted firms

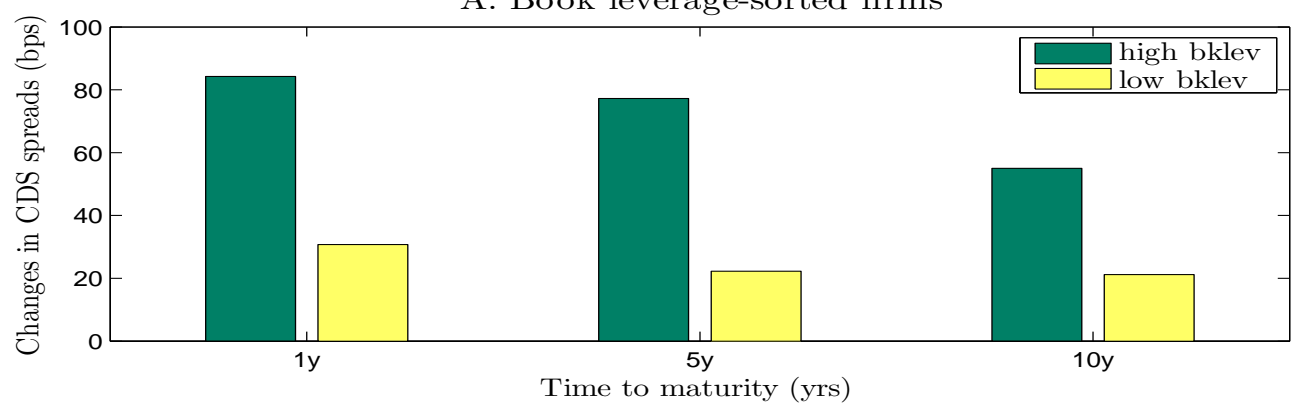

B. Cash flow beta-sorted firms

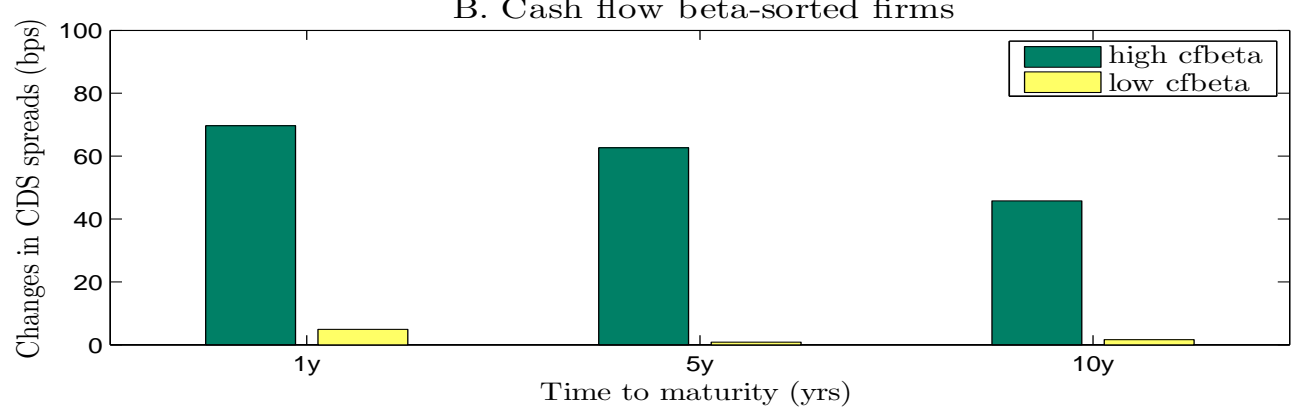

Figure 8: Impact of long-term debt structure on credit spreads. This graph shows the impact of a one-standard deviation increase in the proportion of long-term debt that matures in 2008 on the changes in the CDS spreads between 2007 and 2008. Panel A and B displays the result for firms sorted on book leverage and cash-flow beta, respectively.

in 2008. These results confirm the empirical findings in $\mathrm{Hu}$ (2010).

We also find that the impact of rollover risk on credit spreads is significantly greater for firms with higher book leverage before the crisis. Panel A of Figure 8 shows that a one-standard deviation increase in ldebt08 raises the 1-year, 5-year, and 10-year CDS spreads by 84 bps, 77 bps, and 55 bps respectively for firms with high book leverage, while the corresponding increase in the CDS spreads is $31 \mathrm{bps}, 22 \mathrm{bps}$, and 21 bps respectively for firms with low book leverage. The result for firms with high market leverage before the crisis is quantitatively similar to that for firms with high book leverage, while the effect of rollover risk on the CDS spreads for firms with low market leverage is smaller than that for firms with low book leverage. The results are consistent with our model's prediction that the credit spreads of a firm with high leverage rise more following a negative aggregate shock, especially when the aggregate shock arrives when a large amount of debt is due. Panel B shows the result for cash flow beta-sorted firms. A one-standard deviation increase in ldebt08 
raises 1-year, 5-year, and 10-year the CDS spreads by 70 bps, 63 bps, and 46 bps respectively for firms with high cash flow beta, while the corresponding increase in the CDS spreads is negligible for firms with low cash flow beta.

One concern about our measure of long-term debt structure in 2007 is its endogeneity. Long-term debt is usually held by various investors and very difficult to renegotiate on short notice, which suggests the long-term debt structure is not easy to adjust. However, Mian and Santos (2011) show that firms with good credit quality did actively manage the maturity of syndicated loans before the financial crisis through early refinancing of outstanding loans. This would imply that firms with high rollover risk according to ldebt08 could be firms with low quality (which might not be fully captured by the controls), which would explain the larger increase in credit spreads during the crisis. To address this concern, we also compute ldebt08 based on balance sheet information from fiscal year $2004(d d 4 /(d d 1+d l t t)), 2005$ $(d d 3 /(d d 1+d l t t))$, and $2006(d d 2 /(d d 1+d l t t))$. We then run cross-sectional regression of changes in the CDS spreads from 2007 to 2008 on ldebt08, industry dummies, and other firm controls measured at the end of the fiscal year 2004-2006, respectively. We obtain almost identical results based on the fiscal year 2006 information as we do using fiscal year 2007 information. The results are slightly weaker for 2005 but no longer significant for $2004 .{ }^{13}$

\section{Conclusion}

We construct a dynamic capital structure model with optimal maturity choice to explain the relation between debt maturity and systematic risk. Our model predicts that firms with high systematic volatility choose longer maturity. Moreover, the maturity structure for firms with higher asset beta will be relatively stable over the business cycle. In contrast, firms with low beta have significantly shorter debt maturity in bad times. We show that these links between systematic risk and debt maturity are important for understanding the effects of debt maturity on the term structure of credit spreads. Finally, we provide empirical evidence

\footnotetext{
${ }^{13}$ Using 2-digit SIC codes to control for industrial effects, we obtain quantitatively similar results for the entire sample and the split samples based on market leverage and cash flow beta. However, the result is not significant for the split samples based on book leverage.
} 
consistent with these predictions. 


\section{References}

Acharya, V. V., H. Almeida, and M. Campello, 2010, "Aggregate Risk and the Choice between Cash and Line of Credit," Working Paper, New York University.

Almeida, H., M. Campello, B. Laranjeira, and S. Weisbenner, 2011, "Corporate Debt Maturity and the Real Effects of the 2007 Credit Crisis," Critical Finance Review, 1, 32-58.

Almeida, H., and T. Philippon, 2007, "The Risk-Adjusted Cost of Financial Distress," Journal of Finance, 62, 2557-2586.

Baker, M., and J. Wurgler, 2002, "Market Timing and Capital Structure," Journal of Finance, 57, 1-32.

Bansal, R., and A. Yaron, 2004, "Risks for the Long Run: A Potential Resolution of Asset Pricing Puzzles," Journal of Finance, 59, 1481 - 1509.

Bao, J., J. Pan, and J. Wang, 2011, "The Illiquidity of Corporate Bonds," Journal of Finance, 66, 911-946.

Barclay, M. J., and C. W. Smith, 1995, "The Maturity Structure of Corporate Debt," Journal of Finance, 50, 609-931.

Barlow, M. T., L. C. G. Rogers, and D. Williams, 1980, Wiener-Hopf Factorization for Matrices, in Séminaire de Probabilités XIV, Lecture Notes in Math. 784 . pp. 324-331, Springer-Verlag, Berlin.

Bhamra, H. S., L.-A. Kuehn, and I. A. Strebulaev, 2010a, "The Aggregate Dynamics of Capital Structure and Macroeconomic Risk," Review of Financial Studies, 23, 4187-4241.

Bhamra, H. S., L.-A. Kuehn, and I. A. Strebulaev, 2010b, "The Levered Equity Risk Premium and Credit Spreads: A Unified Framework," Review of Financial Studies, 23, 645-703.

Bharath, S. T., and T. Shumway, 2008, "Forecasting Default with Merton Distance to Default Model," Review of Financial Studies, 21, 1339-1369. 
Chen, H., 2010, "Macroeconomic Conditions and the Puzzles of Credit Spreads and Capital Structure," Journal of Finance, 65, 2171-2212.

Chen, H., and G. Manso, 2010, "Macroeconomic Risk and Debt Overhang," Working Paper, MIT.

Chen, L., P. Collin-Dufresne, and R. S. Goldstein, 2009, "On the Relation Between the Credit Spread Puzzle and the Equity Premium Puzzle," Review of Financial Studies, 22, 3367-3409.

Chen, L., D. A. Lesmond, and J. Wei, 2007, "Corporate Yield Spreads and Bond Liquidity," Journal of Finance, 62, 119-149.

Choi, J., D. Hackbarth, and J. Zechner, 2012, "Granularity of Corporate Debt: Theory and Tests," Working paper.

Collin-Dufresne, P., and R. S. Goldstein, 2001, "Do Credit Spreads Reflect Stationary Leverage Ratios?," Journal of Finance, 56, 1929-1957.

Diamond, D. W., 1991, "Debt Maturity Structure and Liquidity Risk," Quarterly Journal of Economics, 106, 609-737.

Duffie, D., and D. Lando, 2001, "Term Structures of Credit Spreads with Incomplete Accounting Information," Econometrica, 69, 633-664.

Duffie, D., and K. Singleton, 1999, "Modeling Term Structures of Defaultable Bonds," Review of Financial Studies, 12, 687-720.

Edwards, A. K., L. E. Harris, and M. S. Piwowar, 2007, "Corporate Bond Market Transaction Costs and Transparency," Journal of Finance, 62, 1421-1451.

Erel, I., B. Julio, W. Kim, and M. S. Weisbach, 2011, "Macroeconomic Conditions and Capital Raising," Review of Financial Studies.

Flannery, M. J., 1986, "Asymmetric Information and Risky Debt Maturity Choice," Journal of Finance, 41, 19-37. 
Gomes, J. F., L. Kogan, and M. Yogo, 2009, "Durability of Output and Expected Stock Returns," Journal of Political Economy, 117, 941-986.

Gomes, J. F., and L. Schmid, 2010, "Equilibrium Credit Spreads and the Macroeconomy," Working Paper, University of Pennsylvania.

Greenwood, R., S. Hanson, and J. C. Stein, 2010, "A Gap-Filling Theory of Corporate Debt Maturity Choice," Journal of Finance, 65, 993-1026.

Guedes, J., and T. Opler, 1996, "The Determinants of the Maturity of Corporate Debt Issues," Journal of Finance, 51, 1809-1833.

He, Z., and K. Milbradt, 2012, "Endogenous Liquidity and Defaultable Bonds," Working Paper, University of Chicago and MIT.

Hu, X., 2010, "Rollover Risk and Credit Spreads in the Financial Crisis of 2008," Working paper, Princeton University.

Jarrow, R. A., D. Lando, and S. M. Turnbull, 1997, "A Markov Model for the Term Structure of Credit Risk Spreads," Review of Financial Studies, 10, 481-523.

Jobert, A., and L. Rogers, 2006, "Option Pricing with Markov-Modulated Dynamics," SIAM Journal on Control and Optimization, 44, 2063-2078.

Lando, D., 1998, "On Cox Processes and Credit Risky Securities," Review of Derivatives Research, 2, 99-120.

Leland, H., 1994, "Corporate Debt Value, bond covenants, and Optimal Capital Structure," Journal of Finance, 49, 1213-1252.

Leland, H., 1998, "Agency Costs, Risk Management, and Capital Structure," Journal of Finance, 53, 1213-1243.

Leland, H., and K. B. Toft, 1996, "Optimal Capital Structure, Endogenous Bankruptcy, and the Term Structure of Credit Spreads," Journal of Finance, 51, 987-1019. 
Longstaff, F. A., S. Mithal, and E. Neis, 2005, "Corporate Yield Spreads: Default Risk or Liquidity? New Evidence from the Credit Default Swap Market," Journal of Finance, 60, 2213-2253.

Merton, R. C., 1974, "On the Pricing of Corporate Debt: the Risk Structure of Interest Rates," Journal of Finance, 29, 449-470.

Mian, A., and J. A. Santos, 2011, "Liquidity Risk and Maturity Management Over The Credit Cycle," Working Paper, University of California, Berkeley.

Miller, M. H., 1977, "Debt and Taxes," Journal of Finance, 32, 261-275.

Newey, W. K., and K. D. West, 1987, "A Simple, Positive Semi-definite, Heteroskedasticity and Autocorrelation Consistent Covariance Matrix," Econometrica, 55, 703-708.

Stohs, M. H., and D. C. Mauer, 1996, "The Determinants of Corporate Debt Maturity Structure," Journal of Business, 69, 279-312.

Strebulaev, I. A., 2007, "Do Tests of Capital Structure Theory Mean What They Say?," Journal of Finance, 62, 1747-1787.

Vassalou, M., and Y. Xing, 2004, "Default Risk in Equity Returns," Journal of Finance, 56, $831-868$.

Zhou, C., 2001, "The Term Structure of Credit Spreads with Jump Risk," Journal of Banking and Finance, 25, 2015-2040. 
Table 1: Baseline model parameters and results. Panel A contains the parameters used in the baseline model and the results on capital structure and credit spreads. Parameters that do not vary across the states include: $\kappa=\ln 2.5, \sigma_{f}=0.23, C / P=0.05, \tau=0.2$. Panel B summarizes results from the baseline calibration. Market betas are calculated assuming a leverage ratio of $\phi=1.25$ relative to cash flow parameters of the baseline firm which implies market dividend growth rate of $6.36 \%$ and $0.67 \%$ in states $G$ and $B$, and dividend volatilities of $17.0 \%$ and $19.4 \%$ in states $G$ and $B$ respectively. The initial capital structure choices are determined in state $G$.

A. Baseline parameters

\begin{tabular}{lcc}
\hline & state $G$ & state $B$ \\
\cline { 2 - 3 } Transition intensities: $\pi_{s}^{\mathbb{P}}$ & 0.1 & 0.5 \\
Riskfree rate: $r(s)$ & 0.056 & 0.026 \\
Market price of Brownian risk: $\eta(s)$ & 0.15 & 0.24 \\
Cash flow expected growth rate: $\mu^{\mathbb{P}}(s)$ & 0.062 & 0.016 \\
Cash flow systematic volatility: $\sigma_{\Lambda}(s)$ & 0.136 & 0.156 \\
Recovery rate: $\alpha(s)$ & 0.72 & 0.59 \\
Non-default spread parameter: $\ell_{0}(s)$ & $6.11 E-6$ & $3.56 E-3$ \\
Non-default spread parameter: $\ell_{1}(s)$ & 0.592 & 0.104 \\
\hline
\end{tabular}

B. Baseline model results

\begin{tabular}{lcc}
\hline & state $G$ & state $B$ \\
\cline { 2 - 3 } Initial market leverage: $D / V$ & $29.2 \%$ & $32.4 \%$ \\
Initial interest coverage: $y_{0} / C$ & 2.6 & 2.6 \\
Debt maturity: $1 / m_{s}$ & 5.5 & 5.0 \\
5 year default rate & $0.7 \%$ & $1.2 \%$ \\
10 year default rate & $4.6 \%$ & $6.0 \%$ \\
5 year credit spread & $31.7 \mathrm{bps}$ & $58.8 \mathrm{bps}$ \\
10 year credit spread & $102.6 \mathrm{bps}$ & $141.1 \mathrm{bps}$ \\
Conditional equity Sharpe ratio & 0.12 & 0.22 \\
\hline
\end{tabular}


Table 2: Debt maturities and default risk. This table reports 5 year cumulative default probabilities in the two states for combinations of high/low asset beta, high/low leverage, and long/short maturity. High (low) beta corresponds to a firm with average systematic cash-flow volatility of $18.9 \%$ (8.9\%), which is obtained by rescaling the systematic volatility of the benchmark firm and adjusting the idiosyncratic volatility to keep the average total volatility the same as the benchmark firm; at optimal capital structure, the high (low) beta firm has average asset beta of 1.08 (0.52). High (low) leverage corresponds to an initial interest coverage $\left(y_{0} / C\right)$ of $1.3(2.6)$. Long (short) maturity means the debt maturities for both states are set to 7 (3) years.

\begin{tabular}{|c|c|c|c|c|c|c|c|}
\hline \multirow[b]{2}{*}{ Leverage } & \multirow[b]{2}{*}{ Maturity } & \multicolumn{2}{|c|}{ High Beta } & \multirow[b]{2}{*}{$B-G$} & \multicolumn{2}{|c|}{ Low Beta } & \multirow[b]{2}{*}{$B-G$} \\
\hline & & $G$ & $B$ & & $G$ & $B$ & \\
\hline \multirow{3}{*}{ High Lev } & Long & 23.27 & 30.92 & 7.65 & 2.29 & 3.66 & 1.37 \\
\hline & Short & 36.30 & 47.33 & 11.03 & 4.25 & 6.47 & 2.21 \\
\hline & $S-L$ & 13.02 & 16.41 & 3.39 & 1.96 & 2.80 & 0.84 \\
\hline \multirow{3}{*}{ Low Lev } & Long & 1.89 & 3.05 & 1.17 & 0.06 & 0.13 & 0.06 \\
\hline & Short & 3.84 & 5.90 & 2.06 & 0.14 & 0.29 & 0.15 \\
\hline & $S-L$ & 1.95 & 2.84 & 0.89 & 0.07 & 0.16 & 0.09 \\
\hline
\end{tabular}


Table 3: Summary Statistics and Correlation. This table presents summary statistics of firm-level variables in the entire sample and correlation coefficients among risk measures.

\begin{tabular}{|c|c|c|c|c|c|c|}
\hline \multicolumn{7}{|c|}{ A. Summary statistics } \\
\hline & mean & std & median & $25 \%$ & $75 \%$ & obs \\
\hline ldebt1y & 0.737 & 0.287 & 0.852 & 0.611 & 0.954 & 94,618 \\
\hline ldebt2y & 0.631 & 0.306 & 0.723 & 0.436 & 0.878 & 71,649 \\
\hline ldebt3y & 0.525 & 0.315 & 0.580 & 0.265 & 0.785 & 71,649 \\
\hline ldebt4y & 0.434 & 0.310 & 0.450 & 0.137 & 0.687 & 71,649 \\
\hline ldebt5y & 0.349 & 0.295 & 0.323 & 0.045 & 0.581 & 71,649 \\
\hline debtmat & 4.762 & 2.595 & 4.733 & 2.547 & 6.835 & 71,649 \\
\hline mkat & 5.580 & 2.055 & 5.398 & 4.032 & 7.006 & 92,932 \\
\hline abnearn & 0.014 & 0.261 & 0.009 & -0.038 & 0.050 & 84,068 \\
\hline bklev & 0.299 & 0.171 & 0.271 & 0.165 & 0.399 & 94,618 \\
\hline $\mathrm{mk} 2 \mathrm{bk}$ & 1.583 & 1.157 & 1.218 & 0.953 & 1.735 & 92,932 \\
\hline assetmat & 4.584 & 4.692 & 3.086 & 1.805 & 5.444 & 91,175 \\
\hline profitvol & 0.063 & 0.064 & 0.042 & 0.024 & 0.075 & 67,818 \\
\hline mertondd & 5.542 & 4.002 & 4.788 & 2.596 & 7.633 & 63,568 \\
\hline asset market beta & 0.879 & 0.637 & 0.798 & 0.454 & 1.201 & 64,827 \\
\hline asset bank beta & 0.507 & 0.450 & 0.471 & 0.230 & 0.745 & 64,827 \\
\hline asset tail beta & 0.669 & 0.607 & 0.618 & 0.270 & 1.009 & 64,517 \\
\hline equity market beta & 1.128 & 0.746 & 1.068 & 0.659 & 1.518 & 64,827 \\
\hline cash flow beta & 1.773 & 2.590 & 1.410 & 0.105 & 3.260 & 21,507 \\
\hline assetvol & 0.386 & 0.198 & 0.338 & 0.255 & 0.462 & 64,827 \\
\hline sys assetvol & 0.138 & 0.095 & 0.121 & 0.068 & 0.187 & 64,827 \\
\hline id assetvol & 0.347 & 0.181 & 0.301 & 0.221 & 0.423 & 64,827 \\
\hline \multicolumn{7}{|c|}{ B. Correlations } \\
\hline & market beta & bank beta & tail beta & equity beta & cf beta & assetvol \\
\hline bank beta & 0.707 & & & & & \\
\hline tail beta & 0.460 & 0.328 & & & & \\
\hline equity beta & 0.917 & 0.662 & 0.369 & & & \\
\hline cf beta & 0.104 & 0.071 & 0.030 & 0.126 & & \\
\hline assetvol & 0.408 & 0.174 & 0.170 & 0.343 & 0.046 & \\
\hline mertondd & 0.032 & 0.036 & 0.154 & -0.186 & -0.081 & -0.390 \\
\hline
\end{tabular}




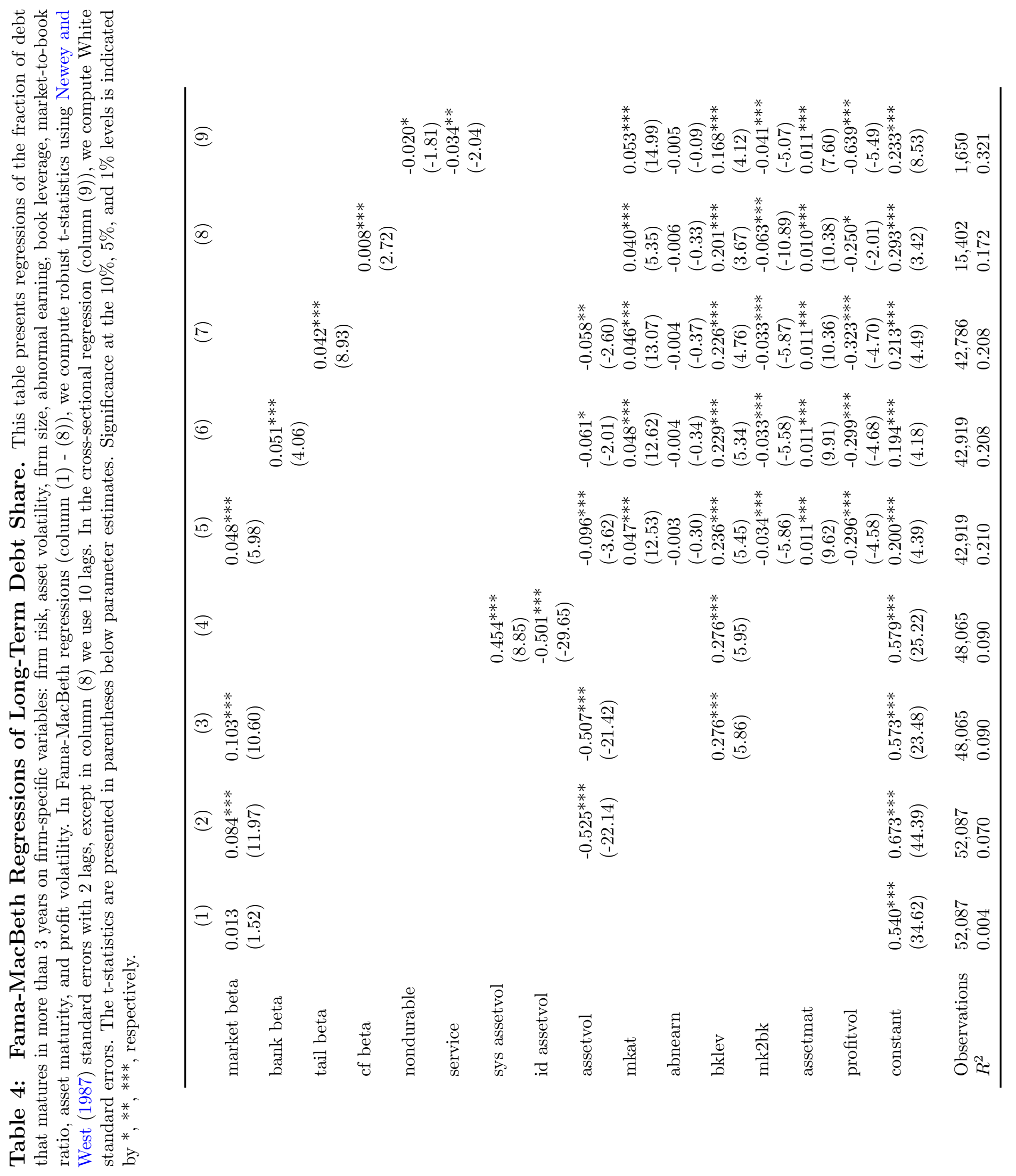


Table 5: Panel Regressions of Long-Term Debt Share. This table presents panel regressions of the fraction of debt that matures in more than 3 years on firm-specific variables: firm risk, asset volatility, firm size, abnormal earning, book leverage, market-to-book ratio, asset maturity, and profit volatility. Industry-fixed effects and year-fixed effects are also included in the regression. We adjust standard errors by clustering the observations at the industry level. Robust t-statistics are presented in parentheses below parameter estimates. Significance at the $10 \%, 5 \%$, and $1 \%$ levels is indicated by $*, * *, * * *$, respectively.

\begin{tabular}{|c|c|c|c|c|c|c|}
\hline & (1) & (2) & $(3)$ & (4) & (5) & (6) \\
\hline market beta & $\begin{array}{l}0.074^{* * *} \\
(19.36)\end{array}$ & $\begin{array}{l}0.087^{* * *} \\
(21.51)\end{array}$ & $\begin{array}{l}0.041 * * * \\
(8.95)\end{array}$ & & & \\
\hline bank beta & & & & $\begin{array}{l}0.037^{* * *} \\
(6.08)\end{array}$ & & \\
\hline tail beta & & & & & $\begin{array}{l}0.036^{* * *} \\
(9.84)\end{array}$ & \\
\hline cf beta & & & & & & $\begin{array}{l}0.004^{* *} \\
(2.15)\end{array}$ \\
\hline assetvol & $\begin{array}{l}-0.426^{* * *} \\
(-23.21)\end{array}$ & $\begin{array}{l}-0.415^{* * *} \\
(-23.90)\end{array}$ & $\begin{array}{l}-0.063^{* * *} \\
(-3.44)\end{array}$ & $\begin{array}{l}-0.019 \\
(-0.98)\end{array}$ & $\begin{array}{l}-0.025 \\
(-1.30)\end{array}$ & \\
\hline mkat & & & $\begin{array}{l}0.047^{* * *} \\
(17.14)\end{array}$ & $\begin{array}{l}0.049^{* * * *} \\
(17.75)\end{array}$ & $\begin{array}{l}0.046^{* * *} \\
(17.20)\end{array}$ & $\begin{array}{l}0.044^{* * *} \\
(11.29)\end{array}$ \\
\hline abnearn & & & $\begin{array}{l}-0.015^{* * *} \\
(-3.43)\end{array}$ & $\begin{array}{l}-0.016^{* * *} \\
(-3.53)\end{array}$ & $\begin{array}{l}-0.014^{* * *} \\
(-3.11)\end{array}$ & $\begin{array}{l}-0.026^{* * *} \\
(-2.93)\end{array}$ \\
\hline bklev & & $\begin{array}{l}0.218^{* * *} \\
(8.59)\end{array}$ & $\begin{array}{l}0.240^{* * *} \\
(8.82)\end{array}$ & $\begin{array}{l}0.231^{* * * *} \\
(8.64)\end{array}$ & $\begin{array}{l}0.234^{* * *} \\
(8.73)\end{array}$ & $\begin{array}{l}0.274^{* * *} \\
(6.61)\end{array}$ \\
\hline $\mathrm{mk} 2 \mathrm{bk}$ & & & $\begin{array}{l}-0.019 * * * \\
(-4.22)\end{array}$ & $\begin{array}{l}-0.017^{* * *} \\
(-3.88)\end{array}$ & $\begin{array}{l}-0.020^{* * *} \\
(-4.54)\end{array}$ & $\begin{array}{l}-0.036^{* * *} \\
(-4.55)\end{array}$ \\
\hline assetmat & & & $\begin{array}{l}0.008^{* * *} \\
(7.85)\end{array}$ & $\begin{array}{l}0.008^{* * *} \\
(7.73)\end{array}$ & $\begin{array}{l}0.008^{* * *} \\
(7.70)\end{array}$ & $\begin{array}{l}0.005^{* * *} \\
(2.66)\end{array}$ \\
\hline profitvol & & & $\begin{array}{l}-0.333^{* * *} \\
(-4.73)\end{array}$ & $\begin{array}{l}-0.341^{* * *} \\
(-4.84)\end{array}$ & $\begin{array}{l}-0.345^{* * *} \\
(-4.84)\end{array}$ & $\begin{array}{l}-0.286^{* *} \\
(-2.11)\end{array}$ \\
\hline constant & $\begin{array}{l}0.638^{* * *} \\
(82.28)\end{array}$ & $\begin{array}{l}0.568^{* * *} \\
(52.72)\end{array}$ & $\begin{array}{l}0.200^{* * *} \\
(10.82)\end{array}$ & $\begin{array}{l}0.190^{* * *} \\
(10.02)\end{array}$ & $\begin{array}{l}0.205^{* * *} \\
(11.10)\end{array}$ & $\begin{array}{l}0.246^{* * *} \\
(7.63)\end{array}$ \\
\hline Industry Fixed-Effect & Yes & Yes & Yes & Yes & Yes & Yes \\
\hline Year Fixed-Effect & Yes & Yes & Yes & Yes & Yes & Yes \\
\hline Observations & 52,087 & 48,065 & 42,919 & 42,919 & 42,786 & 15,402 \\
\hline$R^{2}$ & 0.070 & 0.078 & 0.162 & 0.160 & 0.161 & 0.121 \\
\hline
\end{tabular}


Table 6: Long-Term Debt Share: Impact of Business Cycles. This table presents regression results of long-term debt share (ldebt3y) on a recession dummy, asset beta, an interaction between the recession dummy with asset beta, firm controls (total asset volatility, firm size, abnormal earning, book leverage, market-to-book ratio, asset maturity, and profit volatility) and industry dummies. We also include either a quadratic time trend or an aggregate trend generated by the H-P filter on the aggregate long-term debt share. We adjust standard errors by clustering the observations at the industry level. Robust t-statistics are presented in parentheses below parameter estimates. Significance at the 10\%, 5\%, and $1 \%$ levels is indicated by $*, * *, * * *$, respectively.

\begin{tabular}{|c|c|c|c|c|c|c|}
\hline & (1) & (2) & (3) & (4) & (5) & (6) \\
\hline rec & $\begin{array}{l}-0.031^{* * *} \\
(-4.01)\end{array}$ & $\begin{array}{l}-0.040^{* * *} \\
(-5.42)\end{array}$ & $\begin{array}{l}-0.042^{* * *} \\
(-5.48)\end{array}$ & $\begin{array}{l}-0.043^{* * *} \\
(-5.63)\end{array}$ & $\begin{array}{l}-0.039 * * * \\
(-5.72)\end{array}$ & $\begin{array}{l}-0.035^{* * *} \\
(-5.85)\end{array}$ \\
\hline market beta & $\begin{array}{l}0.029 * * * \\
(7.95)\end{array}$ & $\begin{array}{l}0.084^{* * *} \\
(20.10)\end{array}$ & $\begin{array}{l}0.046^{* * *} \\
(10.25)\end{array}$ & $\begin{array}{l}0.044^{* * *} \\
(9.44)\end{array}$ & & \\
\hline market beta $\times$ rec & $\begin{array}{l}0.014 \\
(1.63)\end{array}$ & $\begin{array}{l}0.033^{* * *} \\
(3.95)\end{array}$ & $\begin{array}{l}0.026^{* * *} \\
(2.94)\end{array}$ & $\begin{array}{l}0.024^{* * *} \\
(2.75)\end{array}$ & & \\
\hline bank beta & & & & & $\begin{array}{l}0.041^{* * *} \\
(6.83)\end{array}$ & \\
\hline bank beta $\times$ rec & & & & & $\begin{array}{l}0.039^{* * *} \\
(3.17)\end{array}$ & \\
\hline tail beta & & & & & & $\begin{array}{l}0.040^{* * *} \\
(11.06)\end{array}$ \\
\hline tail beta $\times$ rec & & & & & & $\begin{array}{l}0.019^{* *} \\
(2.47)\end{array}$ \\
\hline assetvol & & $\begin{array}{l}-0.411^{* * *} \\
(-24.31)\end{array}$ & $\begin{array}{l}-0.106^{* * *} \\
(-6.42)\end{array}$ & $\begin{array}{l}-0.108^{* * *} \\
(-6.18)\end{array}$ & $\begin{array}{l}-0.062^{* * *} \\
(-3.51)\end{array}$ & $\begin{array}{l}-0.063^{* * *} \\
(-3.66)\end{array}$ \\
\hline mkat & & & $\begin{array}{l}0.046^{* * *} \\
(17.20)\end{array}$ & $\begin{array}{l}0.044^{* * *} \\
(17.75)\end{array}$ & $\begin{array}{l}0.047^{* * *} \\
(17.48)\end{array}$ & $\begin{array}{l}0.045^{* * *} \\
(17.02)\end{array}$ \\
\hline abnearn & & & $\begin{array}{l}-0.015^{* * *} \\
(-3.42)\end{array}$ & $\begin{array}{l}-0.016^{* * *} \\
(-3.41)\end{array}$ & $\begin{array}{l}-0.016^{* * *} \\
(-3.61)\end{array}$ & $\begin{array}{l}-0.015^{* * *} \\
(-3.16)\end{array}$ \\
\hline bklev & & $\begin{array}{l}0.217^{* * *} \\
(8.41)\end{array}$ & $\begin{array}{l}0.233^{* * *} \\
(8.43)\end{array}$ & $\begin{array}{l}0.234^{* * *} \\
(8.41)\end{array}$ & $\begin{array}{l}0.218^{* * *} \\
(8.02)\end{array}$ & $\begin{array}{l}0.223^{* * *} \\
(8.18)\end{array}$ \\
\hline $\mathrm{mk} 2 \mathrm{bk}$ & & & $\begin{array}{l}-0.018^{* * *} \\
(-4.20)\end{array}$ & $\begin{array}{l}-0.018^{* * *} \\
(-4.10)\end{array}$ & $\begin{array}{l}-0.015^{* * *} \\
(-3.57)\end{array}$ & $\begin{array}{l}-0.018^{* * *} \\
(-4.44)\end{array}$ \\
\hline asset mat & & & $\begin{array}{l}0.008^{* * *} \\
(8.12)\end{array}$ & $\begin{array}{l}0.008^{* * *} \\
(7.99)\end{array}$ & $\begin{array}{l}0.008^{* * *} \\
(8.01)\end{array}$ & $\begin{array}{l}0.008^{* * *} \\
(7.94)\end{array}$ \\
\hline profitvol & & & $\begin{array}{l}-0.307^{* * *} \\
(-4.62)\end{array}$ & $\begin{array}{l}-0.320^{* * *} \\
(-5.00)\end{array}$ & $\begin{array}{l}-0.315^{* * *} \\
(-4.73)\end{array}$ & $\begin{array}{l}-0.321^{* * *} \\
(-4.82)\end{array}$ \\
\hline constant & $\begin{array}{l}0.604^{* * *} \\
(80.07)\end{array}$ & $\begin{array}{l}0.624^{* * *} \\
(56.10)\end{array}$ & $\begin{array}{l}0.293^{* * *} \\
(16.36)\end{array}$ & $\begin{array}{l}-0.350^{* * *} \\
(-6.46)\end{array}$ & $\begin{array}{l}0.290^{* * *} \\
(16.19)\end{array}$ & $\begin{array}{l}0.303^{* * *} \\
(16.73)\end{array}$ \\
\hline Quadratic Trend & Yes & Yes & Yes & No & Yes & Yes \\
\hline HP Trend & No & No & No & Yes & No & No \\
\hline Industry Fixed-Effect & Yes & Yes & Yes & Yes & Yes & Yes \\
\hline Observations & 52,087 & 48,065 & 42,919 & 42,919 & 42,919 & 42,786 \\
\hline$R^{2}$ & 0.015 & 0.072 & 0.154 & 0.155 & 0.151 & 0.153 \\
\hline
\end{tabular}


Table 7: Long-Term Debt Structure and Credit Spreads. This table presents estimates from cross-sectional regressions of firm-level yearly changes in CDS spreads from fiscal year 2007 to 2008 on ldebt08, the proportion of long-term debt maturing in 2008, firm controls (market leverage, total asset volatility, firm size, market-to-book ratio, profitability, tangible, equity return, and credit rating), and industry dummies based on the 1-digit SIC code. The regressions are estimated for the entire sample and separately for subsamples of firms formed on the basis of firm characteristics at the end of fiscal year 2007. For the three firm characteristics, the subsamples comprise firms with market leverage, book leverage, and cash flow beta above and below the sample median, respectively. Only coefficient estimates of variables that are consistently statistically significant are reported. Robust t-statistics are presented in parentheses below parameter estimates. Significance at the $10 \%, 5 \%$, and $1 \%$ levels is indicated by $*, * *, * * *$, respectively.

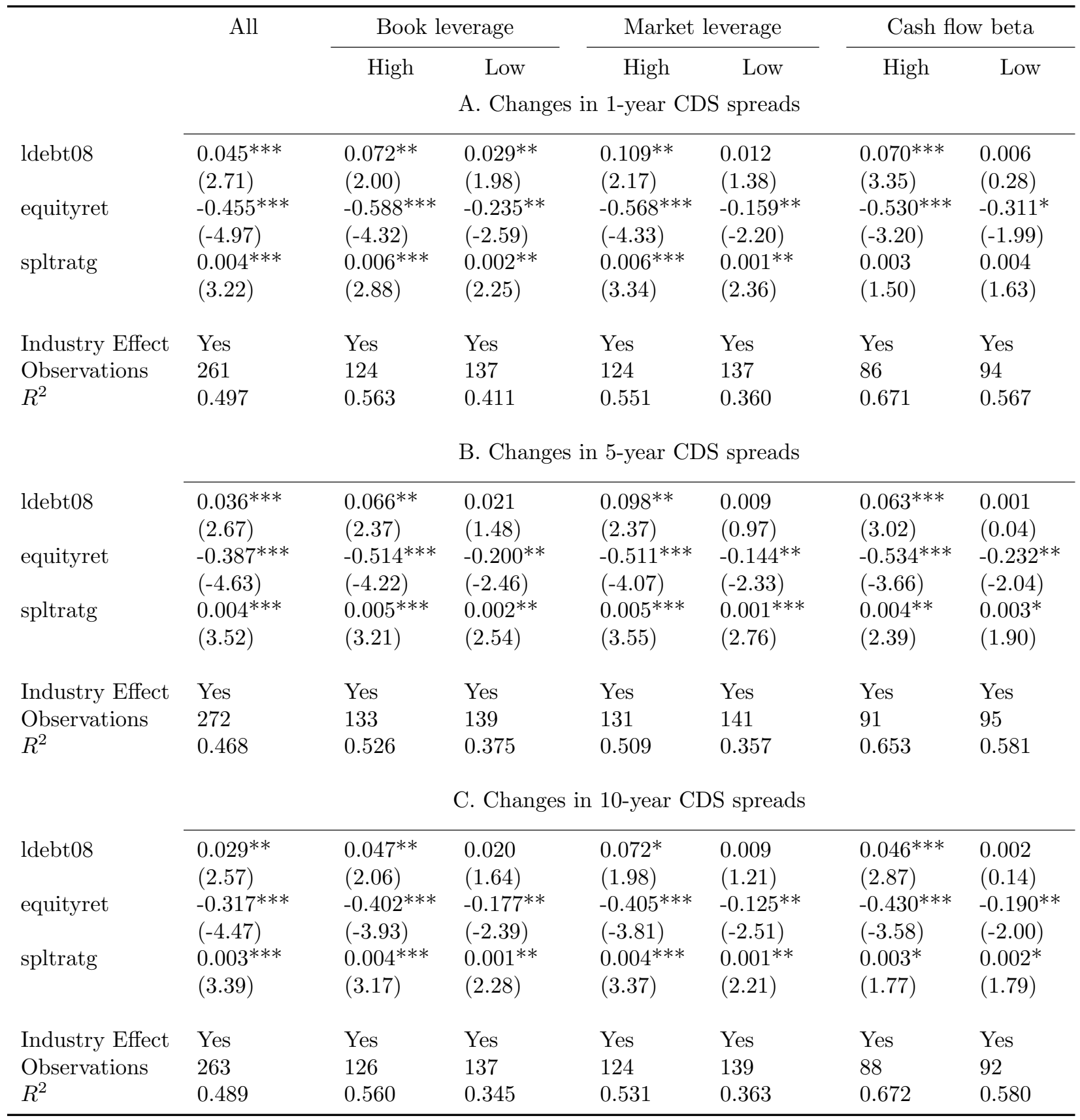




\section{Appendix}

\section{A Model Solution}

This section contains solutions to a generalized model which includes, as special cases, both the baseline 2 state model as well as the 4 state lumpy maturity structure model of Section 2 . There is a total of $\mathcal{S}$ states, whose risk neutral transition intensities are summarized by the matrix $\Pi^{14}$. We also allow parameters to be state dependent: for example, the state dependent risk neutral drifts will be summarized by a $\mathcal{S}$ by 1 vector $\boldsymbol{\mu}$; similar conventions will apply for other parameters. Capital structure choices will imply the tuple $(\mathbf{P}, \mathbf{C}, \mathbf{m}, \boldsymbol{\ell}, \mathbf{\Pi})$ which summarizes, respectively, the state dependent face value of debt, coupons, debt rollover intensities, liquidity costs and the transition matrix. The latter two quantities will, in general, depend on maturity structure.

Valuation equations. The valuation equations will be in terms of $\log$ cash flows $x=\log y$. Given the capital structure, external financing costs $\boldsymbol{\ell}$ and bankruptcy boundaries $\mathbf{x}_{D}=$ $\left\{x_{D}(s)\right\}_{s=1, \ldots, \mathcal{S}}$, debt value at issue, $\mathbf{D}(x)=\{D(x, s)\}_{s=1, \ldots, \mathcal{S}}$, is characterized by the following boundary value problem:

$$
\begin{aligned}
\mathbf{W}_{D} \mathbf{D}(x) & =\mathbf{C}+\mathbf{m} \odot \mathbf{P}+\mathbf{U D}^{\prime}(x)+\mathbf{V D}^{\prime \prime}(x) \\
D\left(x_{D}(s), s\right) & =\alpha(s) v^{*}(x) e^{x_{D}(x)}, \forall s=1, \ldots, \mathcal{S}
\end{aligned}
$$

where we define $\mathbf{W}_{D}=\operatorname{diag}(\mathbf{r})+\operatorname{diag}(\mathbf{m})+\operatorname{diag}(\boldsymbol{\ell})-\boldsymbol{\Pi}, \mathbf{U}=\operatorname{diag}\left(\boldsymbol{\mu}-\frac{1}{2} \boldsymbol{\sigma} \odot \boldsymbol{\sigma}\right)$ and $\mathbf{V}=\operatorname{diag}\left(\frac{1}{2} \boldsymbol{\sigma} \odot \boldsymbol{\sigma}\right)$. We take $\odot$ to mean element-wise multiplication and functions of vectors are applied element-wise. The vector $\mathbf{v}^{*}$ is the firm to cash flow value for the unlevered firm and is given by the generalized Gordon growth formula.

Similarly, the value of equity, $\mathbf{E}(x)=\{E(x, s)\}_{s=1, \ldots, \mathcal{S}}$, is characterized by the following boundary value problem:

$$
\begin{aligned}
\mathbf{W}_{E} \mathbf{E}(x)= & (\mathbf{1}-\boldsymbol{\tau}) \odot\left(e^{x} \mathbf{1}-\mathbf{C}\right)+\mathbf{m} \odot[\mathbf{d}(x)-\mathbf{P}]+\mathbf{U E}^{\prime}(x)+\mathbf{V E}^{\prime \prime}(x) \\
& +\boldsymbol{\Delta}_{1} \mathbf{d}(x)-\boldsymbol{\Delta}_{2} \mathbf{P} \\
E\left(x_{D}(s), s\right)= & 0, \forall s=1, \ldots, \mathcal{S} \\
E_{x}\left(x_{D}(s), s\right)= & 0, \forall s=1, \ldots, \mathcal{S}
\end{aligned}
$$

where we define $\mathbf{W}_{E}=\operatorname{diag}(\mathbf{r})-\boldsymbol{\Pi}$. The matrices $\boldsymbol{\Delta}_{1}$ and $\boldsymbol{\Delta}_{2}$ summarize debt buy backs which occur in the 4 -state model when the state switches from $s_{4}$ to $s_{1}$. That is, in the 4 state model, $\boldsymbol{\Delta}_{1}$ is a 4 by 4 matrix that has a value of $\pi_{B}$ in entry 41 and zero elsewhere, and $\boldsymbol{\Delta}_{2}$ is a 4 by 4 matrix that has a value of $\pi_{B}$ in entry 44 and zero elsewhere; debt buy backs are not present in the 2 state model so that both $\boldsymbol{\Delta}_{1}$ and $\boldsymbol{\Delta}_{2}$ are zero matrices.

\footnotetext{
${ }^{14}$ The $i j$-th non-diagonal entry of $\boldsymbol{\Pi}$ is the risk neutral transition intensity from state $i$ to state $j$. The diagonal entries of $\boldsymbol{\Pi}$ are given by the negative row sums.
} 
Solutions. The derivation for the solutions are similar to those given in Chen (2010): both equity and debt will contain terms of the form $\omega \mathbf{z} e^{-\lambda x}$ where $\omega$ is a weighting scalar the pairs $(\lambda, \mathbf{z})$ are given by solutions to the following quadratic eigenvalue problem (QEP) of the form

$$
\mathbf{W} \mathbf{z}=-\lambda \mathbf{U} \mathbf{z}+\lambda^{2} \mathbf{V} \mathbf{z}
$$

with $\mathbf{W}$ set to $\mathbf{W}_{D}$ and $\mathbf{W}_{E}$, respectively, in the debt and equity solutions. There is a total of $2 \mathcal{S}$ solutions $\left(\lambda_{k}, \mathbf{z}_{k}\right)$ to (A.6), half of which have positive real parts with the other half having negative real parts (see Barlow, Rogers, and Williams (1980)). We discard the solutions with negative real parts as these correspond to explosive solutions.

Whereas the solutions in Jobert and Rogers (2006) and Chen (2010) only involve real eigenvalues, complex eigenvalues may show up for general transition intensities, and the remainder of this section will highlight the main differences in such situations. The complex eigenvalue solutions to (A.6) come in conjugate pairs $(\lambda, \mathbf{z})$ and $(\bar{\lambda}, \overline{\mathbf{z}})$. Since these solutions show up in the valuation equations with an additional weighting term $\omega$, we need only keep the real and complex parts to one of the conjugate pairs in our valuation equation (say the one with the positive complex part). For example, debt value has the form

$$
\begin{aligned}
\mathbf{D}(x)= & \mathbf{D}_{0}+\sum_{k=1}^{N_{D, \mathbb{R}}} \omega_{D, k}^{\mathbb{R}} \mathbf{D}_{1, k}^{\mathbb{R}} e^{-\lambda_{D, k}^{\mathbb{R}} x}+\sum_{k=1}^{N_{D, \mathbb{C}}^{+}} \omega_{D, k}^{\mathbb{C}, R e} \operatorname{Re}\left\{\mathbf{D}_{1, k}^{\mathbb{C}} e^{-\lambda_{D, k}^{\mathbb{C}} x}\right\} \\
& +\sum_{k=1}^{N_{D, \mathbb{C}}^{+}} \omega_{D, k}^{\mathbb{C}, \operatorname{Im}} \operatorname{Im}\left\{\mathbf{D}_{1, k}^{\mathbb{C}} e^{-\lambda_{D, k}^{\mathbb{C}} x}\right\}
\end{aligned}
$$

where $\mathbf{D}_{0}$ is chosen to match the constant term in (A.1), the pairs $\left\{\left(\lambda_{D, k}^{\mathbb{R}}, \mathbf{D}_{1, k}^{\mathbb{R}}\right)\right\}_{k=1}^{N_{D, \mathbb{R}}}$ are the solutions to the QEP with real and positive eigenvalues, and the pairs $\left\{\left(\lambda_{D, k}^{\mathbb{C}}, \mathbf{D}_{1, k}^{\mathbb{C}}\right)\right\}_{k=1}^{N_{D, \mathbb{C}}^{+}}$are the solutions whose eigenvalues have both positive real and complex parts. Finally, there are $\mathcal{S}$ weights $\left\{\omega_{D, k}\right\}_{k=1}^{\mathcal{S}}=\left\{\omega_{D, k}^{\mathbb{R}}\right\}_{k=1}^{N_{D, \mathbb{R}}} \cup\left\{\omega_{D, k}^{\mathbb{C}, R e}\right\}_{k=1}^{N_{D, \mathbb{C}}^{+}} \cup\left\{\omega_{D, k}^{\mathbb{C}, I m}\right\}_{k=1}^{N_{D, \mathbb{C}}^{+}} \subset \mathbb{R}$ used to match $\mathcal{S}$ boundary value conditions (A.2).

The derivation for the equity solution is similar and is omitted for brevity.

\section{B Variable Definition and Data Sources}

- $t d e b t$ (total debt): debt in current liability $(d l c)+$ long-term debt $(d l t t)$. Data source: COMPUSTAT Annual Industrial file.

- ldebt1y (the percentage of total debt that matures in more than 1 year): long-term debt $(d l t t) / t d e b t$. Data source: COMPUSTAT Annual Industrial file.

- ldebt2y (the percentage of total debt that matures in more than 2 years): $(d l t t-d d 2) /$ tdebt. Data source: COMPUSTAT Annual Industrial file. 
- ldebt3y (the percentage of total debt that matures in more than 3 years): (dltt - dd2 dd3) / tdebt. Data source: COMPUSTAT Annual Industrial file.

- ldebt4y (the percentage of total debt that matures in more than 4 years): (dltt - dd2 $d d 3-d d 4)$ / tdebt. Data source: COMPUSTAT Annual Industrial file.

- ldebt5y (the percentage of total debt that matures in more than 5 years): (dltt - dd2 $d d 3-d d 4-d d 5) / t d e b t$. Data source: COMPUSTAT Annual Industrial file.

- mke (market value of equity): share price $\left(\operatorname{prcc}_{f}\right) \times$ common share outstanding $(c s h o)$. Data source: COMPUSTAT Annual Industrial file.

- bke (book value of equity): stockholders' equity (shareholder's equity (seq), if not available, common equity $(c e q)$ + par value of preferred shares (pstk), if not available, total asset $(a t)$ - total liability $(l t))+$ deferred tax and investment tax credit (txditc) book value of preferred shares (redemption value (pstkrv), if not available, liquidation value $(p s t k l)$, if not available, par value $(p s t k))$. Data source: COMPUSTAT Annual Industrial file.

- mkat (market value of total assets): (the market value of equity $(m k e)+$ the book value of total assets (at) - the book value of equity (bke) / GDP deflator, in logs. Data source: COMPUSTAT Annual Industrial file.

- abnearn (abnormal earning): (earnings in year $t+1$ (ibadj) - earnings in year $t$ ) / (share price $\left(\operatorname{prcc}_{f}\right) \times$ outstanding shares $(c s h p r i)$ in year $\left.t\right)$. Data source: COMPUSTAT Annual Industrial file.

- bklev (book leverage): total debt (debt in current liability $(d l c)+$ long-term debt $(d l t t)$ ) / assets (at). Data source: COMPUSTAT Annual Industrial file.

- mklev (market leverage): total debt (debt in current liability $(d l c)+$ long-term debt $(d l t t))$ / the market value of total assets (mkat, not in logs). Data source: COMPUSTAT Annual Industrial file.

- $m k 2 b k$ (market-to-book ratio): the market value of total assets (mkat, not in logs) / the book value of total assets (at). Data source: COMPUSTAT Annual Industrial file.

- profit (profitability): operating income before depreciation (oibdp) / assets (at). Data source: COMPUSTAT Annual Industrial file.

- profitvol (profit volatility): volatility of past 5 years of profit growth (operating income before depreciation in year $t($ oibdp) - operating income before depreciation in year $t-1)) / \operatorname{assets}(a t)$. Data source: COMPUSTAT Annual Industrial file.

- tangible (tangibility): gross property, plant, and equipment (ppent) / assets (at). Data source: COMPUSTAT Annual Industrial file. 
- assetmat (asset maturity): book value-weighted average of the maturities of property, plant and equipment and current assets, computed as (gross property, plant, and equipment $($ ppent $) /$ total assets $($ current assets $($ act $)+$ ppent $) \times($ gross property, plant, and equipment (ppent) / depreciation expense $(d p))+$ (current assets $($ act $) /$ total assets $($ current assets $(a c t)+$ ppent $)) \times($ current assets $($ act $) /$ cost of goods sold $($ cogs $))$. Data source: COMPUSTAT Annual Industrial file.

- market beta (asset market beta): equity market beta computed using past 36 months of equity returns, which is then unlevered based on the Merton model (for details see Vassalou and Xing (2004) and Bharath and Shumway (2008)).

- bank beta (asset bank beta): equity bank beta (with respect to the banking industry portfolio) computed using past 36 months of equity returns, which is then unlevered based on the Merton model (for details see Acharya, Almeida, and Campello (2010)).

- tail beta (asset tail-risk beta): equity tail-risk beta defined as the ratio between (1) the firm average return from the days when the market had the $5 \%$ worst returns in the past year and (2) the average market return on the same days, which is then unlevered based on the Merton model (for details see Acharya, Almeida, and Campello (2010)).

- $c f$ beta (cash-flow beta): defined as the covariance between firm-level and aggregate cash flow changes (normalized by total assets (at) from the previous year) divided by the variance of aggregate cash flow changes; computed using at least 15 years of past 20 years of cash flow data $(i b)$.

\section{Robustness Checks}

We use the proportion of long-term debt that matures in more than 3 years as our benchmark measure of debt maturity in the paper. COMPUSTAT provides the information on the amount of debt that matures in years one through five, and more than five years. Based on these information, we can also construct numerical debt maturity. We obtain very similar results for the cross-sectional and panel regressions using the numerical debt maturity in the regression. ${ }^{15}$ The estimated coefficient on asset beta (with control for book leverage) implies that a one-standard deviation increase in asset beta lengthens firms' debt maturity by 6.7 months. We also obtain similar results using numerical debt maturity in the regression of the impact of business cycles on debt maturity.

To further examine the robustness of our results to different measures of debt maturity, we use the percentage of firms' total debt that matures in more than 1 year, 2 years, 4 years, and 5 years as maturity proxies in the regression. The results are presented in Table A.2. First, we find a similar impact of macroeconomic conditions and asset beta on various long-term debt share measures. Worsening macroeconomic conditions and lower asset betas are associated

\footnotetext{
${ }^{15}$ These results are available upon request.
} 
with shorter debt maturities. Second, high systematic risk firms reduce their debt maturities more from expansions to recessions than low systematic risk firms.

To investigate whether our finding that firms with high systematic risk have longer and more stable debt maturities depends on the 2008 financial crisis, we run regressions using data in a sub-sample period: 1974-2006. Excluding the last four years (2007-2010) of data enable us to examine whether our results are driven by the largest financial crisis since the Great Depression in the 1930s. The results using long-term debt share and numerical debt maturity measures are presented in Table A.3. We obtain quantitatively similar and slightly more significant results by excluding the last four years of data. Coefficient estimates for both the recession dummy, asset betas and their interaction terms are statistically significant in all specifications. Worsening macroeconomic conditions are associated with shortening debt maturities and high exposure to systematic risk are associated with long debt maturities. In addition, the negative relation between the impact of business cycles on debt maturity and firms' asset betas that we find in the entire sample also exist in the sub-sample period. In fact, all the interaction terms between various asset betas and macroeconomic variables are statistically significant across all specifications. The results show that a firm with high systematic risk exposure has a more stable debt maturity over the business cycles. 
Table A.1: Firm Characteristics and the Impact of Business Cycles. This table presents regression results of the impact of business cycles on long-term debt shares with the impact of business cycles to depending on other firm characteristics in addition to asset beta. Standard errors are adjusted by clustering the observations at the industry level. Robust t-statistics are presented in parentheses below parameter estimates. Significance at the $10 \%, 5 \%$, and $1 \%$ levels is indicated by ${ }^{*},{ }^{* *},{ }^{* * *}$, respectively.

\begin{tabular}{|c|c|c|}
\hline & $(1)$ & (2) \\
\hline rec & $\begin{array}{l}0.012 \\
(0.60)\end{array}$ & $\begin{array}{l}0.023 \\
(1.13)\end{array}$ \\
\hline market beta & $\begin{array}{l}0.044^{* * *} \\
(8.61)\end{array}$ & $\begin{array}{l}0.040^{* * *} \\
(7.75)\end{array}$ \\
\hline market beta $\times$ rec & $\begin{array}{l}0.017^{*} \\
(1.93)\end{array}$ & $\begin{array}{l}0.018^{*} \\
(1.96)\end{array}$ \\
\hline mkat & $\begin{array}{l}0.044^{* * *} \\
(15.92)\end{array}$ & $\begin{array}{l}0.043^{* * *} \\
(16.66)\end{array}$ \\
\hline mkat $\times$ rec & $\begin{array}{l}-0.006^{* * *} \\
(-2.64)\end{array}$ & $\begin{array}{l}-0.005^{* *} \\
(-2.23)\end{array}$ \\
\hline abnearn & $\begin{array}{l}-0.011^{*} \\
(-1.93)\end{array}$ & $\begin{array}{l}-0.010 \\
(-1.59)\end{array}$ \\
\hline abnearn $\times$ rec & $\begin{array}{l}-0.013 \\
(-0.85)\end{array}$ & $\begin{array}{l}-0.021 \\
(-1.39)\end{array}$ \\
\hline bklev & $\begin{array}{l}0.312^{* * *} \\
(13.61)\end{array}$ & $\begin{array}{l}0.308^{* * *} \\
(13.38)\end{array}$ \\
\hline bklev $\times$ rec & $\begin{array}{l}-0.045 \\
(-1.51)\end{array}$ & $\begin{array}{l}-0.062^{* *} \\
(-2.10)\end{array}$ \\
\hline mk2bk & $\begin{array}{l}-0.036^{* * *} \\
(-5.26)\end{array}$ & $\begin{array}{l}-0.035^{* * *} \\
(-4.98)\end{array}$ \\
\hline $\mathrm{mk} 2 \mathrm{bk} \times \mathrm{rec}$ & $\begin{array}{l}0.015^{*} \\
(1.86)\end{array}$ & $\begin{array}{l}0.012 \\
(1.48)\end{array}$ \\
\hline assetmat & $\begin{array}{l}0.007^{* * *} \\
(7.13)\end{array}$ & $\begin{array}{l}0.007^{* * *} \\
(7.12)\end{array}$ \\
\hline assetmat $\times$ rec & $\begin{array}{l}0.000 \\
(0.16)\end{array}$ & $\begin{array}{l}0.000 \\
(0.52)\end{array}$ \\
\hline profitvol & $\begin{array}{l}-0.301^{* * *} \\
(-4.09)\end{array}$ & $\begin{array}{l}-0.330^{* * *} \\
(-4.60)\end{array}$ \\
\hline profitvol $\times$ rec & $\begin{array}{l}0.017 \\
(0.15)\end{array}$ & $\begin{array}{l}0.015 \\
(0.14)\end{array}$ \\
\hline mertondd & $\begin{array}{l}0.007^{* * *} \\
(6.92)\end{array}$ & $\begin{array}{l}0.006^{\text {*** }} \\
(6.36)\end{array}$ \\
\hline mertondd $\times$ rec & $\begin{array}{l}-0.003^{* *} \\
(-2.29)\end{array}$ & $\begin{array}{l}-0.005^{* * *} \\
(-3.54)\end{array}$ \\
\hline Quadratic Trend & Yes & No \\
\hline Aggregate Trend & No & Yes \\
\hline Industry-Fixed Effect & Yes & Yes \\
\hline Observations & 39,509 & 39,509 \\
\hline$R^{2}$ & 0.148 & 0.148 \\
\hline
\end{tabular}


Table A.2: Alternative Measures of Long-Term Debt Share. This table presents regression results of various measures of long-term debt share (ldebt1y, ldebt2y, ldebt4y, and ldebt5y) on a recession dummy, asset beta, an interaction between the recession dummy with asset beta, firm controls (total asset volatility, firm size, abnormal earning, book leverage, market-to-book ratio, asset maturity, and profit volatility), industry dummies and a quadratic time trend. We adjust standard errors by clustering the observations at the industry level. Robust t-statistics are presented in parentheses below parameter estimates. Significance at the $10 \%, 5 \%$, and $1 \%$ levels is indicated by $*, * *, * * *$, respectively.

\begin{tabular}{|c|c|c|c|c|c|c|}
\hline \multirow[b]{2}{*}{ rec } & \multicolumn{3}{|c|}{ ldebt1y } & \multicolumn{3}{|c|}{ ldebt2y } \\
\hline & $\begin{array}{l}-0.032 * * * \\
(-5.42)\end{array}$ & $\begin{array}{l}-0.027 * * * \\
(-4.56)\end{array}$ & $\begin{array}{l}-0.028^{* * *} \\
(-4.94)\end{array}$ & $\begin{array}{l}-0.042^{* * *} \\
(-5.42)\end{array}$ & $\begin{array}{l}-0.034^{* * *} \\
(-5.39)\end{array}$ & $\begin{array}{l}-0.034^{* * *} \\
(-5.79)\end{array}$ \\
\hline market beta & $\begin{array}{l}0.041^{* * *} \\
(9.96)\end{array}$ & & & $\begin{array}{l}0.049^{* * *} \\
(11.79)\end{array}$ & & \\
\hline market beta $\times$ rec & $\begin{array}{l}0.021^{* * *} \\
(3.89)\end{array}$ & & & $\begin{array}{l}0.028^{* * *} \\
(3.37)\end{array}$ & & \\
\hline bank beta & & $\begin{array}{l}0.039 * * * \\
(11.54)\end{array}$ & & & $\begin{array}{l}0.047^{* * *} \\
(8.71)\end{array}$ & \\
\hline bank beta $\times$ rec & & $\begin{array}{l}0.029^{* * *} \\
(2.91)\end{array}$ & & & $\begin{array}{l}0.036^{* * *} \\
(3.18)\end{array}$ & \\
\hline tail beta & & & $\begin{array}{l}0.034^{* * *} \\
(10.66)\end{array}$ & & & $\begin{array}{l}0.042^{* * *} \\
(12.00)\end{array}$ \\
\hline tail beta $\times$ rec & & & $\begin{array}{l}0.018^{* * *} \\
(2.64)\end{array}$ & & & $\begin{array}{l}0.020^{* * *} \\
(2.95)\end{array}$ \\
\hline Quadratic Trend & Yes & Yes & Yes & Yes & Yes & Yes \\
\hline Firm Controls & Yes & Yes & Yes & Yes & Yes & Yes \\
\hline Industry Fixed-Effect & Yes & Yes & Yes & Yes & Yes & Yes \\
\hline Observations & 51,812 & 51,812 & 51,644 & 42,919 & 42,919 & 42,786 \\
\hline \multirow[t]{2}{*}{$R^{2}$} & 0.107 & 0.103 & 0.104 & 0.135 & 0.132 & 0.134 \\
\hline & & ldebt4y & & & ldebt5y & \\
\hline rec & $\begin{array}{l}-0.045^{* * *} \\
(-5.94)\end{array}$ & $\begin{array}{l}-0.044^{* * *} \\
(-6.35)\end{array}$ & $\begin{array}{l}-0.033^{* * *} \\
(-5.96)\end{array}$ & $\begin{array}{l}-0.042^{* * *} \\
(-5.86)\end{array}$ & $\begin{array}{l}-0.037^{* * *} \\
(-5.71)\end{array}$ & $\begin{array}{l}-0.034^{* * *} \\
(-6.75)\end{array}$ \\
\hline market beta & $\begin{array}{l}0.038^{* * *} \\
(8.26)\end{array}$ & & & $\begin{array}{l}0.032^{* * * *} \\
(7.29)\end{array}$ & & \\
\hline market beta $\times$ rec & $\begin{array}{l}0.023^{* *} \\
(2.46)\end{array}$ & & & $\begin{array}{l}0.023^{* * *} \\
(2.74)\end{array}$ & & \\
\hline bank beta & & $\begin{array}{l}0.035^{* * *} \\
(5.56)\end{array}$ & & & $\begin{array}{l}0.034^{* * *} \\
(6.02)\end{array}$ & \\
\hline bank beta $\times$ rec & & $\begin{array}{l}0.039^{* * * *} \\
(3.02)\end{array}$ & & & $\begin{array}{l}0.031^{* *} \\
(2.58)\end{array}$ & \\
\hline tail beta & & & $\begin{array}{l}0.037^{* * *} \\
(10.40)\end{array}$ & & & $\begin{array}{l}0.027^{* * *} \\
(7.79)\end{array}$ \\
\hline tail beta $\times$ rec & & & $\begin{array}{l}0.008 \\
(1.19)\end{array}$ & & & $\begin{array}{l}0.015^{* *} \\
(2.35)\end{array}$ \\
\hline Quadratic Trend & Yes & Yes & Yes & Yes & Yes & Yes \\
\hline Firm Controls & Yes & Yes & Yes & Yes & Yes & Yes \\
\hline Industry Fixed-Effect & Yes & Yes & Yes & Yes & Yes & Yes \\
\hline Observations & 42,919 & 42,919 & 42,786 & 42,919 & 42,919 & 42,786 \\
\hline$R^{2}$ & 0.156 & 0.154 & 0.156 & 0.154 & 0.153 & 0.152 \\
\hline
\end{tabular}


Table A.3: Sample Period 1974-2006 (Excluding the Financial Crisis). This table presents regression results of long-term debt share (ldebt3y) on a recession dummy, asset beta, an interaction between the recession dummy with asset beta, firm controls (total asset volatility, firm size, abnormal earning, book leverage, market-to-book ratio, asset maturity, and profit volatility), industry dummies and a quadratic time trend. The sample period is 1974 to 2006 . We adjust standard errors by clustering the observations at the industry level. Robust t-statistics are presented in parentheses below parameter estimates. Significance at the $10 \%, 5 \%$, and $1 \%$ levels is indicated by $*, * *, * * *$, respectively.

\begin{tabular}{|c|c|c|c|c|c|c|}
\hline & \multicolumn{3}{|c|}{ Long-term debt share } & \multicolumn{3}{|c|}{ Numerical debt maturity } \\
\hline & (1) & $(2)$ & $(3)$ & (4) & (5) & (6) \\
\hline rec & $\begin{array}{l}-0.052^{* * *} \\
(-6.98)\end{array}$ & $\begin{array}{l}-0.053^{* * *} \\
(-7.48)\end{array}$ & $\begin{array}{l}-0.039^{* * *} \\
(-6.17)\end{array}$ & $\begin{array}{l}-0.433^{* * *} \\
(-7.01)\end{array}$ & $\begin{array}{l}-0.441^{* * *} \\
(-7.17)\end{array}$ & $\begin{array}{l}-0.342^{* * *} \\
(-7.11)\end{array}$ \\
\hline market beta & $\begin{array}{l}0.048^{* * * *} \\
(9.99)\end{array}$ & & & $\begin{array}{l}0.387^{* * *} \\
(8.78)\end{array}$ & & \\
\hline market beta $\times$ rec & $\begin{array}{l}0.033^{* * *} \\
(4.17)\end{array}$ & & & $\begin{array}{l}0.278^{* * *} \\
(4.18)\end{array}$ & & \\
\hline bank beta & & $\begin{array}{l}0.043^{* * *} \\
(6.90)\end{array}$ & & & $\begin{array}{l}0.380^{* * *} \\
(7.47)\end{array}$ & \\
\hline bank beta $\times$ rec & & $\begin{array}{l}0.058^{* * *} \\
(4.71)\end{array}$ & & & $\begin{array}{l}0.481^{* * *} \\
(4.62)\end{array}$ & \\
\hline tail beta & & & $\begin{array}{l}0.041 \text { *** } \\
(10.65)\end{array}$ & & & $\begin{array}{l}0.329 * * * \\
(10.31)\end{array}$ \\
\hline tail beta $\times$ rec & & & $\begin{array}{l}0.017^{* *} \\
(2.36)\end{array}$ & & & $\begin{array}{l}0.179^{* * *} \\
(3.10)\end{array}$ \\
\hline Quadratic Trend & Yes & Yes & Yes & Yes & Yes & Yes \\
\hline Firm Controls & Yes & Yes & Yes & Yes & Yes & Yes \\
\hline Industry Fixed-Effect & Yes & Yes & Yes & Yes & Yes & Yes \\
\hline Observations & 40,170 & 40,170 & 40,040 & 37,658 & 37,658 & 37,535 \\
\hline$R^{2}$ & 0.155 & 0.152 & 0.153 & 0.165 & 0.162 & 0.163 \\
\hline
\end{tabular}

